\title{
A Systemic Review on Antioxidant and Hepatoprotective Effect of Psidium Guajava Leaf and Fruit Extract
}

\author{
Tesfahun Molla ${ }^{1^{*}} \quad$ Habtamu Azene ${ }^{2}$ \\ 1.School of Medicine, College of Health Sciences and Medicine, Wolaita Sodo University, PO box 138 \\ 2.School of Medicine, College of Health Sciences and Medicine, Wolaita Sodo University
}

\begin{abstract}
Background: Plant derived natural products such as flavonoids, terpenoids, carbohydrates, tannins, saponins, steroids, proteins, amino acids and Vitamin $\mathrm{C}$ have received considerable attention in recent years due to their diverse pharmacological properties including antioxidant and hepatoprotective activity. Psidium guajava (Myrtaceae) is one of such plants in folk medicine that has been used for the management of various disease conditions. Various parts of the plant has been used in traditional medicine.Antioxidants from medicinal plants play an important role in inhibiting and scavenging radicals, thus providing protection to human against infection and degeneration diseases.

Objective: To review the antioxidant and hepatoprotective activity of psidium guajava.

Methods: Computerised literature search was conducted using PubMed, Medline and Google search engine using different key words for studies investigating the antioxidant and hepatoprotective activities of Psidium guajava using the following as heading terms, psidium guajava, antioxidant, hepatoprotectie, Liver injury, oxidative stress. In addition, the reference lists of the retrieved articles helped me to find further articles, relevant to the present review that was not revealed through the searching procedure.

Result: Out of a total of 152 articles on guava resulted 19 studies which were related to antioxidant and hepatoprotective activity of leaf and fruit extract were included in this review.

These were then categorized into six groups; 1) Six studies on in vitro antioxidant studies with leaf extracts, 2) four studies on in vitro antioxidant studies with fruit extract, 3) one in vivo study on antioxidant with leaf extract in rat, 4) one in vivo study on antioxidant with fruit extract in rat, 5) one study antioxidant fruit extract in human and 6) six in vivo studies on hepatoprotective with leaf extract in rat.

Conclusion: The antioxidant activity of Psidium guajava may be due to inhibition of the formation of radicals, scavenging of the formed free radicals, reducing of oxidized intermediates and the presence of the phenolic compounds. It also acts as promising hepato protective which is correlated directly with its ability to reduce activity of serum enzymes and enhance antioxidant defense status. The phenolic content in Psidium guajava extract played a significant role on the antioxidant and hepatoprotective activity.
\end{abstract}

Keywords: guava, Psidium guajava, Antioxidant activity; Radical scavenging; Phenolic compound; Hepatoprotective activity; Carbon tetra chloride; Paracetamol.

\section{Background}

Psidium Guajava is clled Zeytuna in Ethiopia, guayaba in Spanish speaking countries and goiaba in Brazil; guava is a common shade tree or shrub in door-yard gardens in the tropics. It belongs to family of Myrtaceae, genus: psidium, species: guajava and common names of the plant are guava, goiaba, guayaba etc. (Vyas et al., 2010). It is originated in the tropical South America and grows widly in Bangladesh, India, Thailand, Brazil, Florida, and West Indies, California and also in several other countries (Mittal et al., 2010). It is native to and widely distributed in Mexico and Central America. However, the plant is cultivated today from the West coast of Africa to the Pacific regions, including India and China, with varieties originally introduced over the past 300 years from the United States. Generally, guava plant has spread widely throughout the tropics because it thrives in a variety of soils, propagates easily, and bears fruit relatively quickly. The guava berry is an important tropical fruit that is mostly consumed fresh. (Joseph et al., 2011). Guava is rich in antioxidant compounds and contains a high level of ascorbic acid. Both myricetin and apigenin are antioxidants and they were reported to be contained in high amount in Psidium Guajava. It plays a vital role in fulfilling the vitamin C deficiency among the people of the Indian country since $100 \mathrm{~g}$ of fruit contains about $260 \mathrm{mg}$ of vitamins, which is 2-5 times higher than the fresh orange (Rahman et al., 2003). The wood is hard and tough, used as posts for rural house buildings (Mittal et al., 2010). The pharmacological actions and the medicinal uses of aqueous extracts of guava leaves in folk medicine including the treatment of various types of gastrointestinal disturbances such as vomiting, diarrhea, inhibition of the peristaltic reflex, gastroenteritis, spasmolytic activity, dysentery, abdominal distention, flatulence and gastric pain (Lutterodt, 1992). These extracts have also been indicated to cause disturbances of the central nervous system: insomnia, convulsions and epilepsy. Bronchitis, asthma attacks, cough, pulmonary diseases could also be treated with guava teas and could also be useful as anti-inflammatory and homeostatic agent. Moreover, aqueous extracts of guava leaves were described to be effective against a number of microbial strains and anti-rotavirus activity (Mittal et al., 2010). 
Traditional uses: Psidium guajava is an important food crop and medicinal plant in tropical and subtropical countries which is widely used like food and in folk medicine around the world. A survey of the literature shows Psidium guajava is mainly known for its antispasmodic and antimicrobial properties in the treatment of diarrhea and dysentery. It has also been used extensively as a hypo-glycaemic agent. Many pharmacological studies have demonstrated the ability of this plant to exhibit antioxidant, hepato-protective, anti-allergy, antimicrobial, antigenotoxic, antiplasmodial, cytotoxic, antispasmodic, cardioactive, anticough, antidiabetic, anti-inflammatory and antinociceptive activities, supporting its traditional uses (Gutierrez et al., 2008).

\section{Photochemistry}

Psidium Guajava is an important food crop and medicinal plant in tropical and subtropical countries and is widely used like food and in folk medicine around the world. This aims a comprehensive of the chemical constituents and clinical uses of Psidium guajava. Different pharmacological experiments in a number of in vitro and in vivo models have been carried out. Also have been identified the medicinally important phyto-constituents as indicated in Table 1.1 below.

Table 1.1.

Chemical composition of various parts of Guava (Psidium guajava Linn.) (Mittal et al., 2010)

\begin{tabular}{|c|c|}
\hline Parts & Constituents \\
\hline Fruit & $\begin{array}{l}\text { Vitamin C, vitamin A, iron, calcium, manganese, phosphoric, oxalic and malic acids, } \\
\text { saponin combined with oleanolic acid. } \\
\text { Morin-3-O- } \alpha \text {-L-lyxopyranoside and morin-3-O- } \alpha \text {-L-arabopyranoside, flavonoids, } \\
\text { guaijavarin, Quercetin, Myricetin and apigenin. Essential oil contains hexanal ,-2- } \\
\text { hexenal, 2,4-hexadienal, 3-hexenal, 2-hexenal, 3-hexenyl acetate and phenol, while } \\
\beta \text {-caryophyllene,nerolidol, 3-phenylpropyl acetate, caryophyllene oxide, pentane-2- } \\
\text { thiol, 3-penten-2-ol and 2-butenylacetate, 3-hydroxy-2-butano3-methyl-1-butanol, } \\
\text { 2,3-butanediol, 3-methylbutanoic acid, (Z)-3-hexen-1-ol, 6-methyl-5-hepten-2-one, } \\
\text { limonene, octanol, ethyloctanoate(pink guava fruit),fiber,fatty acid. }\end{array}$ \\
\hline Leaves & $\begin{array}{l}\alpha \text {-pinene, } \beta \text {-pinene, limonene, menthol, terpenyl acetate, isopropyl alcohol, } \\
\text { longicyclene, caryophyllene, } \beta \text {-bisabolene, caryophyllene oxide, } \beta \\
\text { copanene,farnesene, humulene, selinene, cardinene and curcumene, mallic acids, } \\
\text { nerolidiol, } \beta \text {-sitosterol,ursolic, crategolic, and guayavolicacids, cineol,quercetin, } 3 \text {-L- } \\
\text { 4-4-arabinofuranoside (avicularin) and } \\
\text { its 3-L-4-pyranoside (Essential oil), resin, tannin eugenol, caryophyllene (1a } \alpha-, 4 a \alpha- \\
, 7 \alpha-, 7 \text { a } \beta \text {-, } 7 \mathrm{~b} \alpha-)] \text {-decahydro-1H-cycloprop[e] azulene, Guajavolide }(2 \alpha-, 3 \beta-, 6 \beta- \\
\text {,23-tetrahydroxyurs-12-en-28,20 } \beta \text {-olide; 1)and guavenoic acid ( } 2 \alpha-, 3 \beta-, 6 \beta-, 23- \\
\text { tetrahydroxyurs-12,20(30)-dien-28-oic acid, triterpene oleanolic acid,triterpenoids, } \\
\text { flavinone-2 2'-ene, prenol,dihydrobenzophenanthridine and cryptonine. }\end{array}$ \\
\hline Bark & polyphenols, resin and crystals of calcium oxalate \\
\hline Root & Tannin, leukocyanidins, sterols, Gallic acid, carbohydrates, salts, tannic acid \\
\hline Seed & $\begin{array}{l}\text { Proteins, starch, oils, phenolic, flavonoid compounds,flavonol glycoside, quercetin-3- } \\
\text { O- } \beta \text {-D-(2"-Ogalloyglucoside)-4'-O-vinylpropionate }\end{array}$ \\
\hline Twigs & $\begin{array}{l}\text { Calcium, magnesium, phosphorous, potassium, sodium, fluoride, copper, iron, zinc, } \\
\text { manganese, and lead. Flavonoids, sesquiterpene alcohols and Acid triterpenoids }\end{array}$ \\
\hline
\end{tabular}

Caloric and nutrient values of psidium guajava

Guava is one of the most popular, nutritionally rich fruit as indicated in (Table 1.2), with unique flavor, taste, and heath promoting qualities making it a common in new functional foods category often called "super fruits". Guavas are low in calories and fats but contains several vital vitamins, minerals and antioxidant poly-phenolic and flavonoid compounds that play important role in prevention of cancers, anti-aging, immune booster etc. (Kamath et al., 2008) 
Table 1.2. Nutrient value per 100g of Guava fruit (Kamath et al., 2008)

\begin{tabular}{|c|c|}
\hline Calories & $77-86 \mathrm{~g}$ \\
\hline Moisture & $2.8-5.5 \mathrm{~g}$ \\
\hline Crude fiber & $0.9-1.0 \mathrm{~g}$ \\
\hline Protein & $0.1-0.5 \mathrm{~g}$ \\
\hline Fat & $0.43-0.7 \mathrm{~g}$ \\
\hline Ash & $9.5-10 \mathrm{~g}$ \\
\hline Carbohydrate & $9.1-17 \mathrm{mg}$ \\
\hline Calcium & $17.8-30 \mathrm{mg}$ \\
\hline Phosphorous & $0.30-0.70 \mathrm{mg}$ \\
\hline Iron & 200-400 I.U \\
\hline Carotene (Vitamin A) & $0.046 \mathrm{mg}$ \\
\hline Thiamin(vitamin B1) & $0.03-0.04 \mathrm{mg}$ \\
\hline Riboflavin(vitamin B2) & $0.6-1.068 \mathrm{mg}$ \\
\hline Niacin & 40 I.U. \\
\hline Vitamin B3 & 35 I.U \\
\hline Ascorbic acid (vitamin C) & $228 \mathrm{mg}$ \\
\hline
\end{tabular}

\section{METHODS}

Computerised literature search was conducted using PubMed, Medline and Google search engines using different strategies for studies investigating the antioxidant and hepatoprotective activities of Psidium guajava using the following as heading terms, psidium guajava, antioxidant, hepatoprotective, liver injury, oxidative stress. In addition, the reference lists of the retrieved articles helped to find further articles, relevant to the present review that were not revealed through the searching procedure.

\section{Inclusion criteria}

A literature search was conducted on Pubmed, Medline and google for research articles relating guava (Psidium guajava) to antioxidant and hepatoprotective activity, in order to determine any potential antioxidant and hepatoprotective activity. A total of 152 articles on guava resulted, of which the 19 studies which were related to antioxidant and hepatoprotective activity of leaf and fruit extract were included in this review.

\section{Data abstraction}

Data from each of 19 articles fulfilling the inclusion criteria (that met the selection criteria) were abstracted.

\section{RESULTS}

Effects of different extracts of psidium guajava on antioxidant enzyme activities and malondialdehyde (MDA) concentration are shown in the table 5.1. There was a significant difference in the antioxidant enzyme activities in the control and treated group with the extracts of P.guajava in all studies. MDA level was also significantly different. Table 5.2 shown the antioxidant activity of Psidium guajava by DPPH free radical scavenging method expressed as IC50.As indicated in the table 5.2 Psidium guajava has moderate antioxidant activity ompared to the standard in both studies. Results of the scavenging activity of plant extracts on hydrogen peroxide, superoxide and DPPH are shown in Table 5.3.It could be seen from table 5.3 that plant extract scavenged $\mathrm{H}_{2} \mathrm{O}_{2}$ and superoxide more effectively than BHA, whereas BHA scascavenged DPPH more effectively than plant 
extract. The effect of Psidium guajava on serum ALT, AST, ALP, bilirubin levels and liver weight are shown in table 5.4 and as shown in the table the values for ALT, AST, ALP, bilirubin and liver weight in all studies are defferent for hepatotoxic group and groups treated with the plant extract.

Table 5.1. Effects of different extracts of psidium guajava on antioxidant enzyme activities and malondialdehyde (MDA) concentration.

\begin{tabular}{|c|c|c|c|c|c|c|}
\hline studies & $\begin{array}{l}\text { Study subject } \\
\text { characteristics }\end{array}$ & $\begin{array}{ll}\text { Plant } & \text { part used } \\
\& & \text { extraction } \\
\text { solvent } & \end{array}$ & $\begin{array}{l}\text { Parameters } \\
\text { measured }\end{array}$ & Control group & Treatment group & $\mathrm{P}$ value \\
\hline $\begin{array}{l}\text { Nor and } \\
\text { Yatim, } \\
2009\end{array}$ & Hypertensive rat & Fruit puree & $\begin{array}{l}\text { GPX } \\
\text { GR }\end{array}$ & $\begin{array}{l}2171.8 \pm 65.9^{\mathrm{a}} \\
126.1 \pm 14.2^{\mathrm{a}}\end{array}$ & $\begin{array}{l}2594.6 \pm 82.8^{\mathrm{d}} \\
148.8 \pm 13.2^{\mathrm{d}}\end{array}$ & $\mathrm{P}<0.05$ \\
\hline $\begin{array}{l}\text { Rahmat A et } \\
\text { al., } 2006\end{array}$ & Human(male) & $\begin{array}{l}\text { Fruit } \\
\text { consumption }\end{array}$ & $\begin{array}{l}\text { GPX } \\
\text { GR } \\
\text { Total } \\
\text { antioxidant }\end{array}$ & $\begin{array}{l}466.32 \pm 145.61 \\
85.06 \pm 26.00 \\
1.35+0.21\end{array}$ & $\begin{array}{l}451.10 \pm 179.56 \\
80.15 \pm 35.94 \\
1.78+0.22 *\end{array}$ & $\mathrm{P}<0.05$ \\
\hline $\begin{array}{ll}\text { Akanji } & e t \\
\text { al., } 2009 & \end{array}$ & Rat & $\begin{array}{ll}\begin{array}{l}\text { Ethanolic leaf } \\
\text { extract }\end{array} & \end{array}$ & $\begin{array}{l}\text { GSH } \\
\text { MDA }\end{array}$ & $\begin{array}{l}0.80 \quad \pm \\
0.12 * * * \\
13.87 \pm 0.53 * * *\end{array}$ & $\begin{array}{l}2.38 \pm 0.14 * * \\
5.86 \quad \pm \\
0.38^{* *}\end{array}$ & $\mathrm{P}<0.05$ \\
\hline $\begin{array}{l}\text { Osman et } \\
\text { al., } 2011\end{array}$ & Rat & $\begin{array}{l}\text { Ethanolic leaf } \\
\text { extract }\end{array}$ & $\begin{array}{l}\text { GSH } \\
\text { SOD } \\
\text { CAT }\end{array}$ & $\begin{array}{l}5.97 \pm 0.34^{\mathrm{c}} \\
14.86 \pm 2.57^{\mathrm{c}} \\
4.88 \pm 0.06^{\mathrm{b}}\end{array}$ & $\begin{array}{l}8.01 \pm 1.05^{\mathrm{ab}} \\
38.68 \pm 1.46^{\mathrm{b}} \\
15.41 \pm 0.31^{\mathrm{a}}\end{array}$ & $\mathrm{P}<0.05$ \\
\hline $\begin{array}{l}\text { Tajua et al., } \\
2010\end{array}$ & Rat & $\begin{array}{l}\text { Aqueous } \\
\text { extracts } \\
\text { leaves }\end{array}$ & $\begin{array}{l}\text { GSH } \\
\text { GPX } \\
\text { SOD } \\
\text { CAT }\end{array}$ & $\begin{array}{l}15.74 \pm 1.13 \\
13.21 \pm 1.77 \\
47.53 \pm 0.93 \\
14.30 \pm 1.01\end{array}$ & $\begin{array}{l}22.30 \pm 1.20 \\
17.16 \pm 0.84 \\
63.81 \pm 1.51 \\
23.40 \pm 1.22\end{array}$ & $\mathrm{P}<0.05$ \\
\hline
\end{tabular}

Table 5.2. Antioxidant activity of Psidium guajava by DPPH free radical scavenging method expressed as IC50.

\begin{tabular}{|l|l|l|l|l|}
\hline Studies & $\begin{array}{l}\text { Plant part used and } \\
\text { extraction solvent }\end{array}$ & $\begin{array}{l}\text { Reference } \\
\text { (IC50 value } \mu \mathrm{g} / \mathrm{mL} .)\end{array}$ & $\begin{array}{l}\text { P.Guajava extracts } \\
(\mathrm{IC50} \\
\mu \mathrm{g} / \mathrm{mL} .)\end{array}$ & P value \\
\hline Vyas et al., 2010 & $\begin{array}{l}\text { Hydroalcholic leaf } \\
\text { extract }\end{array}$ & $\begin{array}{l}\text { Ascorbic acid(25.8 } \\
0.204)\end{array}$ & $45.5 \pm 0.044$ & $\mathrm{P}<0.05$ \\
\hline $\begin{array}{l}\text { Qian and } \\
\text { Nihorimbere, 2004 }\end{array}$ & $\begin{array}{l}\text { Ethanolic guava leaf } \\
\text { extract }\end{array}$ & $\begin{array}{l}\text { Ascorbic } \\
\text { acid(50 0.5) }\end{array}$ & 532.0 & - \\
\hline
\end{tabular}

Table 5.3.Radical scavenging activity of Psidium Guajava expressed by decrement in absorbance.

\begin{tabular}{|c|c|c|c|c|c|c|}
\hline Study & $\begin{array}{l}\text { Plant part } \\
\& \\
\text { extraction } \\
\text { solvents }\end{array}$ & $\begin{array}{ll}\text { Types } & \text { of } \\
\text { radical\& } & \\
\text { absorbance } & \\
\text { maximum } & \end{array}$ & Concentration(mg/ml) & Reference(BHA) & P.guajava & $P$ value \\
\hline $\begin{array}{l}\text { Ogunlana, } \\
2008\end{array}$ & $\begin{array}{l}\text { Leaf } \\
\text { extract of } \\
\text { methanol }\end{array}$ & $\begin{array}{l}\mathrm{DPPH}(517 \mathrm{~nm}) \\
\mathrm{H}_{2} \mathrm{O}_{2}(230 \mathrm{~nm}) \\
\mathrm{O}_{2}-(560 \mathrm{~nm})\end{array}$ & $\begin{array}{l}0.16 \\
0.0543 \\
0.25\end{array}$ & $\begin{array}{l}0.126 \pm 0.001 \\
0.024 \pm 0.003 \\
0.142 \pm 0.001\end{array}$ & $\begin{array}{l}0.282 \pm 0.026 \\
0.014 \pm 0.002 \\
0.011 \pm 0.000\end{array}$ & - \\
\hline
\end{tabular}


Table 5.4. Effect of Psidium guajava on serum ALT, AST, ALP, bilirubin levels and liver weight.

\begin{tabular}{|c|c|c|c|c|c|c|}
\hline studies & $\begin{array}{l}\text { Study subject } \\
\text { characteristics }\end{array}$ & $\begin{array}{l}\text { Plant part used \& } \\
\text { extraction solvent }\end{array}$ & $\begin{array}{l}\text { Parameters } \\
\text { measured }\end{array}$ & $\begin{array}{lr}\text { Only } & \text { PCM or } \\
\mathrm{CCl}_{4} & \text { treated } \\
\text { group } & \end{array}$ & 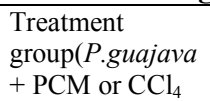 & $\mathrm{P}$ value \\
\hline $\begin{array}{l}\text { Osman et al., } \\
2011\end{array}$ & $\begin{array}{l}\text { Rat treated with } \\
\mathrm{CCl}_{4}\end{array}$ & $\begin{array}{l}\text { Ethanolic leaf } \\
\text { extract }\end{array}$ & $\begin{array}{l}\operatorname{ALT}(\mathrm{u} / \mathrm{mL}) \\
\operatorname{AST}(\mathrm{u} / \mathrm{mL})\end{array}$ & $\begin{array}{l}94.25 \pm 9.05^{\mathrm{a}} \\
198.56 \pm 3.79^{\mathrm{a}}\end{array}$ & $\begin{array}{l}55.05 \pm 6.03^{\mathrm{b}} \\
82.25 \pm 9.38^{\mathrm{b}}\end{array}$ & $\mathrm{P}<0.05$ \\
\hline $\begin{array}{l}\text { Roy and Das, } \\
2010\end{array}$ & $\begin{array}{lll}\text { Rat treated with } \\
\mathrm{CCl}_{4}\end{array}$ & $\begin{array}{l}\text { Methanolic leaf } \\
\text { extract }\end{array}$ & $\begin{array}{l}\text { ALT(u/L) } \\
\operatorname{AST}(\mathrm{u} / \mathrm{L}) \\
\operatorname{ALP}(\mathrm{u} / \mathrm{L}) \\
\operatorname{Serum} \\
\text { bilirubin(mg/dl) } \\
\text { Liver } \\
\text { weight(g/100gm } \\
\text { body weight) }\end{array}$ & $\begin{array}{l}384.00 \pm 25.02^{\mathrm{a}} \\
642.20 \pm 31.01^{\mathrm{a}} \\
749.60 \pm 36.25^{\mathrm{a}} \\
1.56 \pm 0.22^{\mathrm{a}} \\
3.78 \pm 0.30^{\mathrm{b}}\end{array}$ & $\begin{array}{l}16.72 \pm 4.09^{* * *} \\
151.74 \pm 13.95^{* * *} \\
488.82 \pm 10.01^{* * *} \\
0.26 \pm 0.05^{* * *} \\
2.99 \pm 0.12^{*}\end{array}$ & $\begin{array}{l}{ }^{\mathrm{a}} \mathrm{P}<0.001 \\
{ }^{* * * *} \mathrm{p}<0.001 \\
{ }^{\mathrm{b}} \mathrm{p}<0.05\end{array}$ \\
\hline $\begin{array}{l}\text { Tajua et } \\
\text { al., } 2010\end{array}$ & $\begin{array}{l}\text { Rat treated with } \\
\text { PCM }\end{array}$ & $\begin{array}{l}\text { Aqueous extracts of } \\
\text { leaves }\end{array}$ & $\begin{array}{l}\text { ALT(IU/I) } \\
\text { AST(IU/I) } \\
\text { ALP(IU/I) } \\
\text { Bilirubin } \\
\end{array}$ & $\begin{array}{l}84.25 \pm 1.84^{\#} \\
125.73 \pm 2.61^{\#} \\
114.72 \pm 3.01^{\#} \\
4.84 \pm 0.64 \# \\
\end{array}$ & $\begin{array}{l}56.93 \pm 1.83^{*} \\
77.58 \pm 1.56^{*} \\
68.40 \pm 1.42^{*} \\
1.75 \pm 0.05^{*} \\
\end{array}$ & ${ }^{*} \mathrm{P}<0.05$ \\
\hline $\begin{array}{l}\text { Uboha et al., } \\
2010\end{array}$ & Normal male rat & $\begin{array}{l}\text { Leaf aqueous } \\
\text { extract }\end{array}$ & $\begin{array}{l}\text { ALT(IU/L) } \\
\operatorname{AST}(\mathrm{IU} / \mathrm{L}) \\
\operatorname{ALP}(\mathrm{IU} / \mathrm{L})\end{array}$ & $\begin{array}{l}9.02 \pm 2.10 \\
7.12 \pm 2.18 \\
94.20 \pm 4.82\end{array}$ & $\begin{array}{l}8.86 \pm 2.00^{*} \\
6.94 \pm 1.86^{*} \\
93.72 \pm 5.06^{*}\end{array}$ & $* \mathrm{P}<0.05$ \\
\hline $\begin{array}{l}\text { Roy et al., } \\
2006\end{array}$ & PCM treated rat & Aqueous extract & $\begin{array}{l}\text { ALT(U/L) } \\
\text { AST(U/L) } \\
\text { ALP(U/L) } \\
\text { Serum } \\
\text { bilirubin(mg/gl) } \\
\text { Liver } \\
\text { weight(g/100gm } \\
\text { body weight) }\end{array}$ & $\begin{array}{l}384.00 \pm 25.02^{\mathrm{a}} \\
642.20 \pm 31.01^{\mathrm{a}} \\
749.60 \pm 36.38^{\mathrm{a}} \\
1.56 \pm 0.22^{\mathrm{a}} \\
4.40 \pm 0.14^{\mathrm{a}}\end{array}$ & $\begin{array}{l}86.94 \pm 18.94^{* * *} \\
178.92 \pm 8.07^{* * *} \\
338.32 \pm 39.80^{* * *} \\
0.56 \pm 0.04^{* * *} \\
2.88 \pm 0.02^{* * *}\end{array}$ & $\begin{array}{l}{ }^{\mathrm{a}} \mathrm{P}<0.001 \\
{ }^{* * *} \mathrm{p}<0.001\end{array}$ \\
\hline $\begin{array}{l}\text { Roy and Das, } \\
2010\end{array}$ & PCM treated rat & $\begin{array}{l}\text { Methanolic } \\
\text { extract }\end{array}$ & $\begin{array}{l}\text { ALT(U/L) } \\
\text { AST(U/L) } \\
\text { ALP(U/L) } \\
\text { Serum } \\
\text { bilirubin(mg/dl) } \\
\text { Liver weight } \\
\text { (g/100gm body } \\
\text { weight)weight) }\end{array}$ & $\begin{array}{l}378.25+28.45^{\mathrm{a}} \\
645.61+25.38^{\mathrm{a}} \\
758.66+30.58^{\mathrm{a}} \\
1.68+0.20^{\mathrm{b}} \\
4.09+0.33^{\mathrm{c}}\end{array}$ & $\begin{array}{l}132.25+7.73^{* * *} \\
237.48 \\
15.39^{* * *} \\
479.46+7.52^{* * *} \\
0.35+0.09^{* *} \\
3.13+0.07^{* *}\end{array}$ & $\begin{array}{l}{ }^{\mathrm{a}} \mathrm{P}<0.001 \\
{ }^{\mathrm{b}} \mathrm{p}<0.01 \\
{ }^{\mathrm{c}} \mathrm{p}<0.05 \\
{ }^{* *} \mathrm{p}<0.01 \\
{ }^{* * *} \mathrm{p}<0.001\end{array}$ \\
\hline
\end{tabular}

\section{DISCUSSION}

Evidence suggests that compounds especially from natural sources are capable of providing protection against free radicals. Many solvents are used for extraction of bioactive compounds from the plants. The solvents used vary in their polarity. The most commonly used solvent is methanol. This suggested that the polarity of the active components in guava leaves was lower than water. Since the polarity of methanol was slightly lower than water, this was considered to be one of the most suitable solvents for extraction (Tachakittirungrod et al., 2007), similar observation was obtained in (okonogi et al., 2007). Traditionally, water is used for extraction but it is next to methanol. The use of non polar solvents is comparatively less indicating that the active constituents are soluble in polar solvents only. Generally, any part of the plant can be used for antioxidant studies but most commonly used part is leaf followed by fruit (Chanda and Dave, 2009).

\section{Antioxidant activity of Psidium Guajava}

In vitro antioxidant studies - Guava leaf extracts

In the study conducted in Taiwan (Yin and Chin, 2007), to determine the antioxidant activity in a linoleic acid system. The antioxidant activities of extracts from guava, using the thiocyanate method (Mitsuda et al., 1996), has been determined and compared with that of polyphenon 60, which is a commercial polyphenol product extracted from green tea. Comparison of antioxidant activity of the extracts from guava at various concentrations is shown in Table 6.1 . 
Table 6.1. (Yin and Chin, 2007)

Antioxidant activities of extracts from leaves and dried fruit of guava

\begin{tabular}{llllrlrll}
\hline Sample concentration $(\mu \mathrm{g} / \mathrm{ml})$ & \multicolumn{6}{l}{ Peroxidation $(\%)^{\mathrm{a}}$} \\
\cline { 2 - 8 } & Shi Ji Ba & \multicolumn{1}{l}{ Shui Jing Ba } & \multicolumn{1}{l}{ Tu Ba } & \multicolumn{1}{c}{ Hong Ba } & Guava tea A & Guava tea B & Dried fruit & Tea polyphenon 60 \\
\hline 50 & $9.3 \pm 0.4$ & $14.3 \pm 1.9$ & $13.0 \pm 2.6$ & $15.6 \pm 1.1$ & $20.6 \pm 2.9$ & $17.8 \pm 2.6$ & $49.9 \pm 2.7$ & $17.8 \pm 1.8$ \\
100 & $3.8 \pm 0.1$ & $4.0 \pm 0.2$ & $4.4 \pm 0.4$ & $5.0 \pm 0.3$ & $5.7 \pm 1.3$ & $4.7 \pm 0.2$ & $11.6 \pm 0.8$ & $10.1 \pm 1.1$ \\
150 & $4.5 \pm 0.1$ & $4.1 \pm 0.1$ & $4.6 \pm 0.1$ & $4.9 \pm 0.2$ & $3.8 \pm 0.1$ & $3.7 \pm 0.2$ & $7.3 \pm 0.3$ & $11.3 \pm 0.4$ \\
200 & $4.7 \pm 0.2$ & $4.8 \pm 0.4$ & $4.8 \pm 0.1$ & $4.5 \pm 0.1$ & $3.4 \pm 0.2$ & $4.5 \pm 0.1$ & $4.8 \pm 0.2$ & $13.1 \pm 0.4$ \\
500 & $9.0 \pm 0.3$ & $8.0 \pm 0.1$ & $8.7 \pm 0.3$ & $8.9 \pm 0.1$ & $6.3 \pm 0.2$ & $6.2 \pm 0.2$ & $0.7 \pm 0.1$ & $19.5 \pm 1.2$ \\
\hline
\end{tabular}

${ }^{\mathrm{a}}$ Peroxidation $(\%)=[($ absorbance of sample at $500 \mathrm{~nm}) /($ absorbance of control at $500 \mathrm{~nm})] \times 100$. A low peroxidation $(\%)$ indicated a high antioxidant activity.

In all samples, the extracts from Shi Ji Ba showed a stronger antioxidant activity than did other samples at $50 \mu \mathrm{g} / \mathrm{ml}$. However, the extracts from guava leaves and dried fruit all exhibited 95\% inhibition at a concentration of $200 \mu \mathrm{g} / \mathrm{ml}$. Except for the dried fruit extracts, the other samples were found to have weaker antioxidant activity when the concentration was over $200 \mu \mathrm{g} / \mathrm{ml}$. The polyphenon 60 showed strong significant prooxidant effects and the maximum antioxidant activity was weaker than those of extracts from guava leaves and guava tea at a concentration of $100 \mu \mathrm{g} / \mathrm{ml}$. The extracts from dried fruit of guava displayed weaker antioxidant activity than did other samples at $50 \mu \mathrm{g} / \mathrm{ml}$. However, there was no significant difference in antioxidant activity $(\mathrm{P}>0.05)$ between dried fruit of guava and other guava extracts at a concentration of 200 $\mathrm{lg} / \mathrm{ml}$. In the above results, the results indicated that $94.4-96.2 \%$ of linoleic acid oxidation was inhibited by the addition of guava leaf and guava tea extracts at a concentration of $100 \mu \mathrm{g} / \mathrm{ml}$. The guava dried fruit extracts exhibited weaker antioxidant effects than did the leaf extracts (Yin and Chin, 2007). The chromatogram data in this study indicated that guava extracts contained phenolic acids, such as ferulic acid, which appeared to be responsible for their antioxidant activity.

The study in India by Vyas and his colleague (Table 5.3) investigated antioxidant activity of Psidium Guajava leaf extract by DPPH free radical scavenging method using ascorbic acid as standard. The extract of Psidium Guajava leaf extract was found to possess strong antioxidant activity (Vyas et al., 2010). This activity of Psidium Guajava extract may be attributed to their free radical-scavenging ability. The extent of antioxidant activity of $P$. Guajava extract was found significant as compared to standard. The antioxidant activity was expressed as IC50; it is the measure of concentration in $\mu \mathrm{g} / \mathrm{ml}$ of extract that inhibits $50 \%$ of DPPH radicals. IC50 value for Psidium Guajava linn leaves extract was found to be $45.5 \mu \mathrm{g} / \mathrm{ml}$. Thus Psidium Guajava linn leaves possess moderate antioxidant activity as compared to the standard, ascorbic acid (Table 6.2). In the same study the reducing power of Psidium Guajava linn leaves extract was studied using potassium ferricyanide reduction method, the amount of $\mathrm{Fe}^{2+}$ complex was then monitored by measuring the formation of Pearl's Prussian blue at $700 \mathrm{~nm}$.As shown in (Table 6.3) the reducing power of the test drug extract of Psidium guajava increased with increase in concentration. Increased absorbance of the reaction mixture indicated the increased reducing power, thus it is clear that Psidium Guajava linn leaves extract possess significant reducing power.

Table 6.2. Antioxidant activity by DPPH method (Vyas et al., 2010)

\begin{tabular}{|c|c|c|}
\hline S.No. & Sample & IC50 value $(\mu \mathrm{g} / \mathrm{mL})$ \\
\hline 1. & $P$. Guajava extract & $45.5 \pm 0.044$ \\
\hline 2. & Ascorbic acid(standard) & $25.8 \pm 0.204$ \\
\hline
\end{tabular}

The data are expressed as mean value $\pm S D(n=3)$. All values are significant at $\mathrm{P}<0.05$.

Calculated using Graph Pad (ANOVA).

Table 6.3. Reducing power method (Vyas et al., 2010)

\begin{tabular}{|l|l|l|l|}
\hline S.No. & $\begin{array}{l}\text { Concentration }(\mu \mathrm{g} / \mathrm{mL}) \\
\text { P.guajava } \text { extract }\end{array}$ & P. Guajava Absorbance & Ascorbic acid Absorbance \\
\hline 1. & 20 & $0.483 \pm 0.002$ & $0.33 \pm 0.001$ \\
\hline 2. & 40 & $0.704 \pm 0.012$ & $0.47 \pm 0.014$ \\
\hline 3. & 60 & $0.815 \pm 0.01$ & $0.62 \pm 0.200$ \\
\hline 4. & 80 & $0.901 \pm 0.2$ & $0.74 \pm 0.001$ \\
\hline 5. & 100 & $0.982 \pm 0.06$ & $0.82 \pm 0.010$ \\
\hline
\end{tabular}

The data are expressed as mean value $\pm \mathrm{SD}(\mathrm{n}=3)$. All values are significant at $\mathrm{P}<0.05$.

Calculated using Graph Pad (ANOVA)

Ferric reducing ability of plasma (FRAP) reducing power was also determined as a mechanism of antioxidant action of guava leaf extract (Tachakittirungrod et al., 2007). The principle of the FRAP method is based on the reduction of a ferric-tripyridyltriazine complex to its ferrous colored form in the presence of antioxidants. The reducing power property indicates that the antioxidant compounds are electron donors and can 
reduce the oxidized intermediates of the lipid peroxidation process. Figure 6.1 shows the reducing power of guava leaf extracts from different solvents. All extracts had reducing power but not at the same level. The result clearly indicated that the methanol extract of guava leaves had the highest reducing power with the equivalent concentration (EC) value of $3.65 \pm 0.038 \mathrm{mM} / \mathrm{mg}$ extract which is due to its polarity effect to extract most of the active ingredients. This was much higher than that of Butylated hydroxyl toluene (BHT) but a little lower than qiercetin (QCT). BHT and QCT were used as a Reference. The ethyl acetate and butanol extracts showed lower activity with EC values of $1.15 \pm 0.132$ and $1.36 \pm 0.032 \mathrm{mM} / \mathrm{mg}$ extract, respectively, which were about $31-37 \%$ less than that of the methanol extract. The lowest reducing property was obtained from the hexane fraction. From this point of view, it was confirmed that the methanol fraction of guava leaves possessed highest level of the potent antioxidant compounds. According to its high EC value, it could be considered that compounds in the methanol fraction were good electron donors and could terminate oxidation chain reactions by reducing the oxidized intermediates into the stable form. Therefore the results demonstrated that the mechanism of antioxidant action of guava leaf extracts was free radical scavenging and reducing of oxidized intermediates. The phenolic content in guava leaf fraction played a significant role on the antioxidant activity via reducing mechanisms. Like alpha-tocopherol (vitamin E), phenolic compounds contain chemical structural elements that may be responsible for their antioxidant activities.

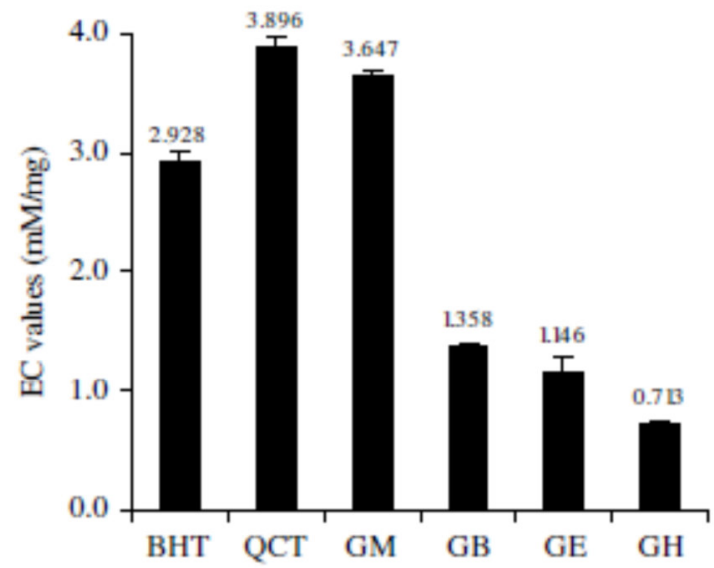

Figure 6.1.Reducing power of Guava leaf extracts from Methanol (GM), Butanol (GB), Ethyl acetate (GE) and Hexane $(\mathrm{GH})$ in comparison with those of butylated hydroxyl toluene(BHT) and Quercetin (QCT).

(Tachakittirungrod et $a l ., 2007$ )

In the study mentioned above three free radicals were used to assess the potential free radicalscavenging activities of guava extracts, namely 2, 2-Azinobis (3-ethylbenzothiazoline-6-sulfonate $\left(\right.$ ABTS $^{+}$) radical, superoxide anion and peroxy radicals (Yin and Chin, 2007). The reduced ABTS is a peroxidase substrate which, when oxidized in the presence of $\mathrm{H}_{2} \mathrm{O}_{2}$ in a typical peroxidative reaction, generates a metastable radical with a characteristic absorption spectrum at maximum absorption value of $414 \mathrm{~nm}$ (Arnao et al., 1996). The $\mathrm{ABTS}^{+}$radicals are scavenged by antioxidants via the mechanism of electron-/hydrogen-donation and are assessed by measuring the decrease in absorption at $414 \mathrm{~nm}$. In the superoxide anion-scavenging test, superoxide anion that is derived from dissolved oxygen through the Phenazine Metho sulfate (PMS/NADH) coupling reaction reduces Nitroblue tetrazolium (NBT) and increases absorption at $560 \mathrm{~nm}$. The decrease in absorption at $560 \mathrm{~nm}$ with antioxidants indicates the consumption of superoxide anion. In the peroxyl radical-scavenging assay, the ability of extracts from guava to scavenge peroxyl radicals was measured by monitoring the loss of $\beta$ phycoerythrin fluorescence induced by 2, 2-Azo-bis, 2-amidinopropane dihydrochloride (AAPH). Thermal decomposition of AAPH leads to the formation of carbon-centred radicals which, under aerobic conditions, yield alkylperoxyl radicals. These radical species can be detected by assay of fluorescent decomposition of $\beta$ phycoerthrin, a major pigment protein of sea algae. The absorption assay for antioxidants was based on oxidation of $\beta$-phycoerthrin molecules by peroxyl radicals. The inhibitions of guava leaf extracts on the fluorescent decomposition of $\beta$-phycoerthrin, induced by AAPH, increased with concentration $(2.5-10 \mathrm{lg} / \mathrm{ml})$ up to a maximum, and then decreased at the concentration $25-50 \mathrm{lg} / \mathrm{ml}$. This finding was similar to the results of the antioxidant activity assay in a linoleic acid system. The prooxidant effects of guava extracts at high concentrations may be correlated with phenoxy radical formed by the change of phenolic compounds with phenoxy radical reacted with $\beta$-phycoerythrin to participate in radical chain propagation.

Correlation analysis between the antioxidant properties and phenolic compounds of extracts from leaves and dried fruit of guava indicated that there was a linear relationship between antioxidant potency, free radicalscavenging ability and the content of phenolic compounds of guava leaf extracts (Yin and Chin, 2007). The calculated coefficients of correlations between antioxidant activity, scavenging effects on radicals and contents of phenolic compounds of guava extracts are shown in table 6.4. The antioxidant activity of guava extracts was 
significantly correlated with their scavenging effects on superoxide anion $(\mathrm{P}<0.01), \mathrm{ABTS}^{+}$radicals $(\mathrm{P}<0.01)$ and peroxyl radicals $(\mathrm{P}<0.05)$. Therefore, the antioxidant activities of guava extracts may be due to their scavenging effects on radicals and blocking of the chain reaction in the peroxidation of linoleic acid. For scavenging effects on radicals, high correlations $(\mathrm{R}=0.921-0.991)$ were observed between various radicals, indicating that these three methods have satisfactory correlations for the examination of antioxidants. The antioxidant activity $(\mathrm{P}<0.05)$ and scavenging effects on superoxide anion, $\mathrm{ABTS}^{+}{ }^{+}$radicals and peroxyl radicals $(\mathrm{P}<0.01)$ of guava extracts was also well correlated with their contents of total phenolic compounds. The same trends were observed in the correlation of the content of gallic acid and the antioxidant activity and scavenging effects on superoxide anion. According to recent reports, a highly positive relationship existed between total phenolics and antioxidant activity in many plant species (Nabasree and Bratati, 2004, Dorman and Hiltunen, 2004).

In another study in China by Qian and Nihorimbere, as shown in table 5.2 antioxidant activity of different extracts from guava leaf according to the $\mathrm{DPPH}^{*}$ radical scavenging method was determined. The results in (figures 6.2 and 6.3) showed that the decrease in absorbance of the DPPH radical was due to its reduction by different antioxidants. Absorbance decreases as a result of a color change from purple to yellow as the radical was scavenged by antioxidant through donation of hydrogen to form the stable DPPH-H. The data showed that $\mathrm{DPPH}^{*}$ solution was bleached with all the samples tested. However, differences could be observed through different antioxidants used and their concentrations.

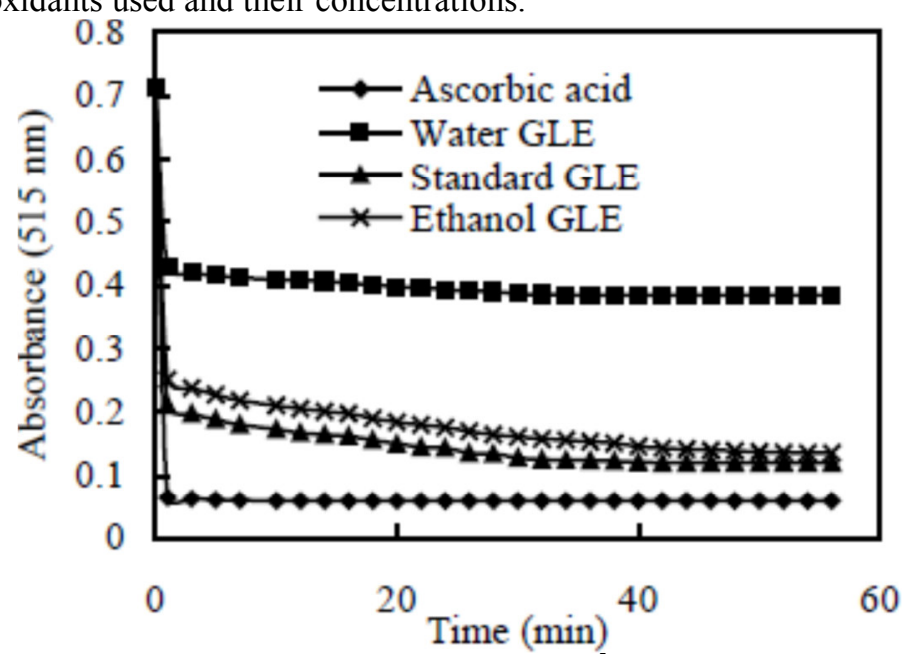

Figure 6.2.Time course of absorbance reduction of $4 \mathrm{ml}$ of $6 \times 10^{-5} \mathrm{~mol} / \mathrm{L} 2$,2-diphenyl-1-picrylhydryzyl (DPPH') in methanol and each tested sample (ascorbic acid, water GLE, ethanol GLE, standard GLE) at concentration: $0.25 \mathrm{mg} / \mathrm{ml}$, by the decolorization reaction of $\mathrm{DPPH}^{*}$ radical from purple to yellow. GLE: guava leaf extracts (Qian and Nihorimbere, 2004).

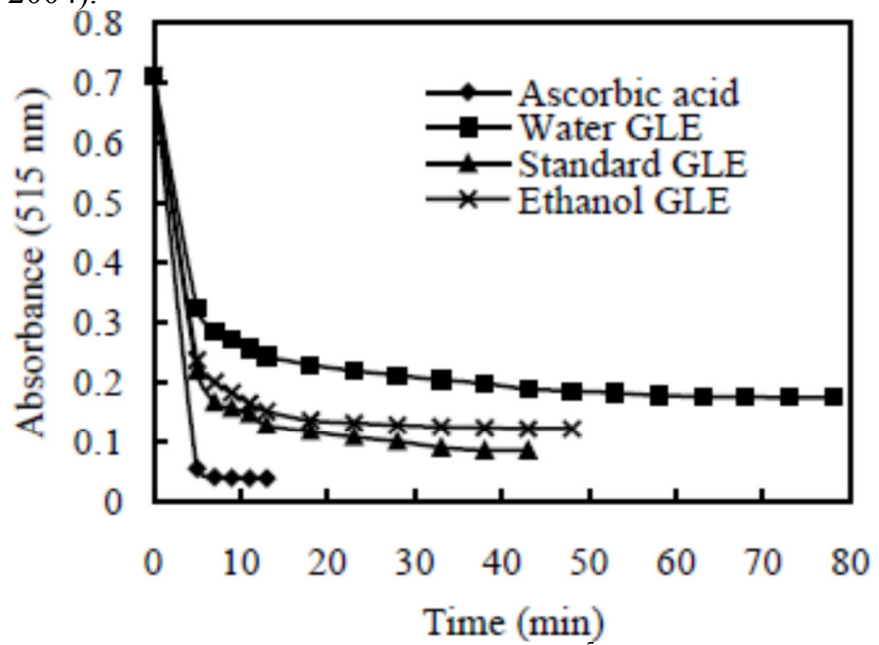

Figure 6.3. Time course of absorbance reduction of $4 \mathrm{ml}$ of $6 \times 10^{-5} \mathrm{~mol} / \mathrm{L}$ 2,2-diphenyl-1-picrylhydryzyl (DPPH') in methanol and each tested sample (ascorbic acid, water GLE, ethanol GLE, standard GLE) at concentration:0.5 $\mathrm{mg} / \mathrm{ml}$, by the decolorization reaction of $\mathrm{DPPH}^{*}$ radical from purple to yellow. GLE: guava leaf extracts. (Qian and Nihorimbere, 2004). 
Table 6.4.Correlation between the antioxidant properties and phenolic compounds of extracts from leaves and dried fruit of Guava (Yin and Chin, 2007)

\begin{tabular}{|c|c|c|c|c|c|c|c|}
\hline & \multirow[t]{2}{*}{ Antioxidant activity ${ }^{a}$} & \multicolumn{3}{|l|}{ Scavenging effects ${ }^{a}$} & \multicolumn{3}{|c|}{ Phenolic compounds } \\
\hline & & Superoxide anion & $\mathrm{ABTS}^{+}$radicals & Peroxyl radicals & Total & Gallic acid & Ferulic acid \\
\hline Antioxidant activity & 1.000 & & & & & & \\
\hline \multicolumn{8}{|l|}{ Scavenging effects } \\
\hline Superoxide anion & $0.876^{\circ}$ & 1.000 & & & & & \\
\hline $\mathrm{ABTS}^{+}$radicals & $0.880^{\circ}$ & $0.991^{*}$ & 1.000 & & & & \\
\hline Peroxyl radicals & $0.853^{\circ *}$ & $0.92 \mathrm{l}^{*}$ & $0.944^{*}$ & 1.000 & & & \\
\hline \multicolumn{8}{|l|}{ Phenolic compounds } \\
\hline Total & $0.797^{\circ *}$ & $0.927^{*}$ & $0.909^{\circ}$ & $0.875^{\circ}$ & 1.000 & & \\
\hline Gallic acid & $0.810^{* *}$ & $0.759^{* *}$ & 0.698 & 0.585 & 0.688 & 1.000 & \\
\hline Ferulic acid & 0.685 & $0.763^{* *}$ & 0.729 & $0.63 \mathrm{I}$ & 0.682 & $0.895^{\circ}$ & 1.000 \\
\hline
\end{tabular}

Table 6.5 shows that ascorbic acid is superior inhibitor of $\mathrm{DPPH}^{\cdot}$ compared to guava leaf extracts. From (Table 6.5), ascorbic acid showed high percentage inhibition while standard guava leaf extracts, ethanol guava leaf extracts and water guava leaf extracts respectively, showed decreasing inhibition effect for all concentrations.

Table 6.5.Comparison of antioxidant activity of guava leaf extracts with ascorbic acid expressed as \% inhibition (Qian and Nihorimbere, 2004)

\begin{tabular}{|l|l|l|l|l|}
\hline $\begin{array}{l}\text { Concentration } \\
(\mathrm{mg} / \mathrm{mL})\end{array}$ & $\begin{array}{l}\text { Ascorbic } \\
\text { acid }\end{array}$ & $\begin{array}{l}\text { STD } \\
\text { (GLE) }\end{array}$ & $\begin{array}{l}\text { Ethanol } \\
(\mathrm{GLE})\end{array}$ & $\begin{array}{l}\text { Water } \\
(\mathrm{GLE})\end{array}$ \\
\hline 0.1 & 35.76 & 31.69 & 27.62 & 18.23 \\
\hline 0.25 & 91.58 & 83.02 & 75.87 & 46.14 \\
\hline 0.4 & 92.42 & 85.69 & 80.92 & 47.12 \\
\hline 0.5 & 94.38 & 87.79 & 82.74 & 75.13 \\
\hline
\end{tabular}

GLE: Guava leaf extract, STD: Standard

For all the antioxidants, with higher the concentrations, the bleaching ability of the DPPH' solution was nearly complete. Ascorbic acid was substantially more active in all the concentrations used (Table 6.5) in comparison with different extracts from guava leaf. With high concentration of ascorbic acid, it was possible to observe nearly a 100\% free radical scavenging effect. Ethanol GLE and standard GLE had nearly the same effect for the similar concentrations used. As for ascorbic acid, ethanol GLE, standard GLE, water GLE, a clear gradient activity was seen from the first to the last concentration used (Table 6.5). Ascorbic acid, known to act as antioxidant and different extracts from guava leaf showed good free radical-scavenging activity depending on the concentration used. The higher the concentration used the higher the free radical-scavenging effect. Total phenolic content values of standard GLE, ethanol GLE and water GLE were 598.25 $\pm 4,575.3 \pm 15.5$ and $511.6 \pm 6.2 \mathrm{mg}$ of gallic acid equivalent $(\mathrm{GAE}) / \mathrm{g}$ of dry weight material, respectively. The average of total phenolic content of standard, ethanol and water GLE were significantly different at $P<0.005$. Ascorbic acid, a potential antioxidant, was used as positive control of antioxidant activity compared with the extracts of guava leaf found to contain significant amounts of natural phenolics that are antioxidants. Guava leaf extracts (GLE) analysis revealed they contain different phenolic compounds such as 1-tannic acid; 2-procatechuic acid; 3-caffeic acid; 4-ferulic acid; 5-rutin trihydrate; 6-quercetin dihydrate (the HPLC profile was not reported). Due to the diversity and complexity of the natural mixtures of phenolic compounds in the different extracts of guava leaf, it is rather difficult to characterize every compound and assess or compare their antioxidant activities (Zheng and Wang, 2001). This study showed that the amount of ethanol guava leaf extracts to total phenolic content was higher than that of water guava leaf extracts. Moreover, it can be seen from (Table 6.5) that ethanol GLE exhibited higher antioxidant activity (expressed in terms of percentage inhibition) than water guava leaf extracts for all the concentrations tested. Antioxidant activity of the extracts may also be attributable to unidentified substances or to synergistic interactions. Therfore guava leaf extracts showed potential antioxidant activity and can be used to extend the shelf life of foodstuffs, to reduce wastage and nutritional losses by inhibiting and delaying oxidation. The higher the sample concentration used, the stronger was the free radical scavenging effect. Increased intake of guava leaf extracts is therefore good for our health. 
In another In vitro study by (Ogunlana , 2008),Assessment of the ability of the extract to scavenge the Reactive Oxygen Species (ROS), hydrogen peroxide, superoxide and the synthetic radical 1,1-Diphenyl-2picrylhydrazyl(DPPH) was determined with reference to the synthetic antioxidant Buth ylated hydroxyanisole (BHA) as indicated in (Table 5.2). Plant extract showed concentration- dependent scavenging activity on all reactive species used. Scavenging activity of plant extract on hydrogen peroxide and superoxide was more than that of BHA on same concentration. The remarkable mop-up potential of hydrogen peroxide and superoxide by the plant leaves could present a possible amelioration for the damages connected with hydroxyl radical to macromolecules by the following mechanisms among others:

Scavenging hydrogen peroxide, Scavenging superoxide anion radical and inhibiting the formation of hydroxyl radical from both hydrogen peroxide and superoxide as powered by Haber-Weiss reaction. Hydrogen peroxide only initiates lipid peroxidation weakly (Cohen and Heikkila, 1974). However, its ability to produce active oxygen species is due to its ability to generate highly reactive hydroxyl radical through the Fenton reaction (Namiki , 1990). The ability of plant extract to scavenge $\mathrm{H}_{2} \mathrm{O}_{2}$ could also reflect its ability to inhibit the formation of hydroxyl radical in vivo.However, BHA showed greater DPPH scavenging activity than plant extract. This may have been due to BHA's possession of a methoxy group which increases the accessibility of the radical centre of DPPH to BHA (Chin and Der, 1994).In the study in Thailand investigating Antioxidant Active Principles Isolated from Psidium guajava Grown in Thailand (okonogi et al., 2007). Antioxidant active compounds were isolated from methanol crude extracts of the leaves of Guava (Psidium guajava L.) grown in Thailand. The isolated compounds were screened for their in vitro antioxidant activity by a DPPH free radical scavenging assay. Results indicate that three isolated compounds contribute importantly to the antioxidant activity of guava leaves, providing a scientific basis for the use of this plant in traditional medicine. Their structures were determined on the basis of spectroscopic and chemical methods. The most active compound was found to be quercetin along with two flavonoid compounds, quercetin-3-O-glucopyranoside and morin.In this study; the comparative biological activity of three compounds isolated from guava leaves was evaluated as their antioxidant capacity to scavenge DPPH free radicals. It was found that all three isolated principles, quercetin, quercetin-3-O-glucopyranoside and morin had antioxidant activity but at different levels as with the IC50 of $1.20 \pm 0.02,3.58 \pm 0.05$ and $5.41 \pm 0.20 \mu \mathrm{g} / \mathrm{ml}$, respectively. It was clearly seen that quercetin is the most active principle in Thai guava leaves, followed by quercetin-3-O-glucopyranoside and morin, respectively. This result could be explained by the higher antioxidant activity being related to the greater number of hydroxyl groups on the falconoid nucleus.

\section{Human study - Guava fruit extracts}

Human study in Malaysia (Rahmat et al., 2006),investigating the effects of guava (Psidium guajava) consumption on total antioxidant status as indicated in (Table 5.1) and lipid profile (total cholesterol, triglycerides, LDLcholesterol and HDL-cholesterol) in 28 normal male youth the study was carried out over nine weeks, which was divided into three phases, that is, baseline (one week), treatment (four weeks) and control (four weeks).There was a significant increase of total antioxidants during the treatment phase, compared to the baseline and control phases $(\mathrm{p}<0.05)$. The increase in total antioxidant status was probably due to increased antioxidant consumption contributed from guava which has been reported to be high in antioxidant vitamins such as ascorbic acid, $\beta$-carotene, lutein, zeaxanthin and lycopene. There were trends of reduction for both glutathione peroxidase and glutathione reductase in the treatment phase as compared to baseline and control phases. However, the reduction was not statistically significant. The reduction of antioxidant enzymes was associated with decreased oxidative stress and decrease in free radical activities, because antioxidant in plasma can act as a good indicator of oxidative stress in humans (Polidori et al., 2001).The consumption of guava, therefore, could result in improved antioxidant status. Thus, it could reduce the risk of disease caused by free radical activities.

\section{In Vitro antioxidant Studies - Guava fruit Constituents}

Study in Spain by Marquina and his colleagues (Marquina et al., 2008) measured the total polyphenol content and antioxidant capacity of the peel, shell, and pulp of the fresh guava fruit. Processed guava pulp and jam were also analyzed. The phenolic content was highest in the guava skin (10 times higher antioxidant capacity than pulp), and lowest in the jam.

In another Correlation study between Some Nutritional Components and the total Antioxidant Capacity, Measured with Six Different Assays in Eight Horticultural Crops (Corral et al., 2008) in vitro measurements of total antioxidant capacity (AOC) of guava and other fruit extracts was conducted. Total soluble phenolics, vitamin $\mathrm{C}$, vitamin $\mathrm{E}, \beta$-carotene, and total carotenoids were correlated with the total AOC of hydrophilic and lipophilic extracts from guava,avocado, mango, papaya, prickly pear fruit, and strawberry. Among the assays, hydrophilic extracts (HPEs) of guava had the highest AOC value, whereas those from the papaya and prickly pear fruit the lowest values.

In Similar study exhibited (Thaipong et al., 2005) at evaluating hydrophilic antioxidant activity (AOAH) 
and the lipophilic antioxidant activity (AOAL); and their correlations with vitamin $\mathrm{C}$, and total phenolic and $\beta$ carotene contents in fresh guava fruits of one white flesh clone and three pink flesh clones Both white and pink flesh guavas showed high hydrophilic antioxidant activity and compounds for phenolic and vitamin $\mathrm{C}$ indicated that regular consumption of guava might be beneficial to health. That hydrophilic antioxidant activity, the major activity, had high correlations with both total phenolic and vitamin $\mathrm{C}$ indicated that the use of the total phenolic or vitamin $\mathrm{C}$ content to determine antioxidant activity level in guava fruit was feasible. Phenolic and vitamin $\mathrm{C}$ are the major contributors to the antioxidant activity of guava fruits, while the contribution of carotenoid is negligible.

In the study investigating guava Fruit (Psidium guajava L.) as a New Source of Antioxidant Dietary Fiber (Jiménez-Escrig et al., 2001), Pulp and peel fractions of p.guajava were tested, and both showed high content of dietary fiber (48.55-49.42\%) and extractable polyphenols (2.62-7.79\%). The antioxidant activity of polyphenol compounds was studied, using three complementary methods: (i) free radical DPPH scavenging, (ii) ferric reducing antioxidant power assay (FRAP), and (iii) inhibition of copper-catalyzed in vitro human lowdensity lipoprotein (LDL) oxidation. All fractions tested showed a remarkable antioxidant capacity, and this activity was correlated with the corresponding total phenolic content. A 1-g (dry matter) portion of peel contained DPPH activity, FRAP activity, and inhibition of copper-induced in vitro LDL oxidation, equivalent to $43 \mathrm{mg}, 116 \mathrm{mg}$, and $176 \mathrm{mg}$ of Trolox, respectively. These results indicate that guava could be a suitable source of natural antioxidants. Peel and pulp could also be used to obtain antioxidant dietary fiber (AODF), a new item which combines in a single natural product the properties of dietary fiber and antioxidant compounds.

\section{In Vivo Antioxidant Studies - Guava leaf extract}

In vivo antioxidant related study was one investigating the effects of the aqueous leaf extract of $P$. guajava on reduced glutathione(GSH) and malondialdehyde (MDA) concentrations in rats experimentally infected with Trypanosoma brucei brucei (Akanji et al., 2009). In this study it was demonstrated that T. brucei infection resulted in high amounts of MDA and low concentrations of GSH as indicated in (Table 5.2).In the T. bruceiinfected animals however the aqueous extract of $P$. guajava leaf was able to reduce the trypanosomosis associated lipid peroxidation as well as raise the level of GSH in the treatment group. It was speculated that the ability of the leaf extract of $P$. guajava to lower the MDA concentrations in the treatment group may be attributed to its antioxidant properties.

\section{In Vivo Antioxidant Studies - Guava fruit extract}

In another in vivo study(Nor and Yatim , 2009) aimed to determine the effects of pink guava puree supplementation on enzyme activities (Table 5.1), and kidney and liver function by carrying out tests on Spontaneous Hypertensive Rats (SHR). Twenty-four male SHR were divided into four groups [control, CG (distilled water); low dosage group, LDG $(0.5 \mathrm{~g} / \mathrm{kg}$ body weight); medium dosage group, MDG (1.0 g/ $/ \mathrm{kg}$ body weight); high dosage group, HDG $(2.0 \mathrm{~g} / \mathrm{kg}$ body weight)]. The results of this study indicated that the specific activities of glutathione peroxidase (GPx) was significantly higher in LDG (2332.5 \pm 81.8 U/l), MDG (2424.8 $\pm 97.1 \mathrm{U} / 1)$ and HDG (2594.6 $\pm 82.8 \mathrm{U} / 1)$ respectively, as compared to CG (2171.8 $\pm 65.9 \mathrm{U} / 1)$. Significant differences were also seen in glutathione reductase (GR) activities among all treated groups [LDG (132.5 \pm 11.8 U/1), MDG (141.5 $\pm 16.4 \mathrm{U} / 1)$, HDG (148.8 $\pm 13.2 \mathrm{U} / \mathrm{l})$ compared to CG $(126.1 \pm 14.2 \mathrm{U} / \mathrm{l})]$. The result, Therefore, indicated that administering pink guava puree to the HFD-induced obese rats significantly increased those antioxidant enzyme activities. The benefits of Guajava plant-based foods may be a consequence of bioactive phytochemicals found in these foods.

These findings therefore, suggested that the single ingestion of leaf or fruit extract can act as antioxidant via free radical scavenging and reducing oxidized intermediates, the phenolic content in guava leaf and fruit fraction played a significant role on the antioxidant activity.

\section{HEPATOPROTECTIVE ACTIVITY OF PSIDIUM GUAJAVA}

All studies reviewed under this section were in vivo hepatoprotective studies of Guava leaf extract.

\section{Carbon tetrachloride $\left(\mathrm{CCl}_{4}\right)$ and Paracetamol (PCM) as a cause of Hepatotoxisity}

Carbon tetrachloride and paracetamol converted into reactive oxidative metabolites by hepatic microsomal enzymatic system, which causes hepatotoxicity (Brent and Rumack, 1993).It is well documented that $\mathrm{CCl}_{4}$ is biotransformed under the action of cytochrome P450 in the microsomal compartment of liver to trichloromethyl radical which readily reacts with molecular oxygen to form trichloromethyl peroxy radical. The hepatotoxic effects of $\mathrm{CCl} 4$ are largely due to its active metabolite trichloromethyl radical and trichloromethyl peroxy radical. Both the radicals can bind covalently to the macromolecules and induce peroxidative degradation of the membrane lipids of endoplasmic reticulum rich in polyunsaturated fatty acids. This leads to the formation of lipid peroxides followed by various changes in biochemical parameters (Sangeetha and krishnakumari, 
2010).PCM overdose causes severe hepatotoxicity that leads to liver failure in both humans and experimental animals a small amount of PCM is metabolized together with cytochrome P450. As a result, N-acetyl-pbenzoquinone imine (NAPQI) or Nacetyl-p-benzosemiquinone imine (NAPSQI) appears in the body's system. Both these compounds are very active chemical and their chemical structures indicate that they are capable of taking part in free radical reactions. Consequently, PCM overdose can lead to a number of unfavorable consequences, especially those affecting the liver. A large dose of this drug causes depletion of GSH level in the liver, because NAPQI reacts rapidly with glutathione, which consequently exacerbates oxidative stress in conjunction with mitochondrial dysfunction. Thus, the GSH depletion, especially occurring in acute hepatotoxicity, affects liver functions and leads to massive hepatocyte necrosis, liver failure or death (Tajua et $a l$., 2010).

\section{Toxicity study on p.guajava}

The toxicology study was performed on the leaves of Psidium guajava L. calculating mean lethal dose in Swiss mice and alternative toxicology in Wistar rats. No deaths were observed in the toxicological results of the two experimental models in the dose range using up to $2 \mathrm{~g} / \mathrm{kg}$ body weight. Acute toxicity tests in rats and mice have proven the LD50 of guava leaf extracts to be more than $5 \mathrm{~g} / \mathrm{kg}$. (Roy et al., 2006, Gupta et al., 2011, Roy and Das, 2010).

\section{Effect of P.guajava on serum enzymes and total bilirubin levels in hepatotoxicity}

The study in India evaluated the hepatoprotective activity of Psidium guajava (PGJ) in acute experimental liver injury induced by paracetamol (PCM) as indicated in table (5.4) (Tajua et al., 2010). Serum transaminases, ALP and total bilirubin levels are susceptible to hepatotoxin and serve as markers of liver damage which promotes the release of such serum enzymes from hepatocytes into blood stream. The effects of pretreatment with P.guajava and silymarin on the PCM-induced elevation of serum enzymes AST, ALT, ALP and total bilirubin activities are shown in (Table 6.6). PCM induced elevation were found to be $125.73 \pm 2.61 \mathrm{IU} \mathrm{L}^{-1}$ in AST, $84.25 \pm 1.84 \mathrm{IU} \mathrm{L}^{-1}$ in ALT and $114.72 \pm 3.01 \mathrm{IU} \mathrm{L}^{-1}$ in ALP indicating that PCM have inflicted a significant damage to liver (Table 6.6)

Table 6.6. Effect of Psidium guajava on serum marker enzymes and total bilirubin level in PCM induced hepatotoxicity in rat. (Tajua et al., 2010).

\begin{tabular}{llllll}
\hline SNo. & Groups & $\begin{array}{c}\text { AST } \\
\text { (IU/l) }\end{array}$ & $\begin{array}{c}\text { ALT } \\
\text { (IU/l) }\end{array}$ & $\begin{array}{l}\text { ALP } \\
\text { (IU/l) }\end{array}$ & $\begin{array}{l}\text { Total bilirubin } \\
\text { (mg/dl) }\end{array}$ \\
\hline I & Control & $76.52 \pm 1.37$ & $55.46 \pm 2.35$ & $63.61 \pm 1.09$ & $1.51 \pm 0.15$ \\
II & PCM treated & $125.73 \pm 2.61 \#$ & $84.25 \pm 1.84 \#$ & $114.72 \pm 3.01 \#$ & $4.84 \pm 0.64 \#$ \\
III & PCM+Silymarin & $79.78 \pm 1.59^{*}$ & $56.98 \pm 1.79^{*}$ & $70.40 \pm 1.48^{*}$ & $1.81 \pm 0.11^{*}$ \\
IV & PCM+P.guajava & $77.58 \pm 1.56^{*}$ & $56.93 \pm 1.83^{*}$ & $68.40 \pm 1.42^{*}$ & $1.75 \pm 0.05^{*}$
\end{tabular}

\section{Explanations: Each value represents the mean \pm SD of six animals. \#significant difference at $P<0.05$ (BMRT) compared with the control. * significant difference at $\quad P<0.05$ (BMRT) compared with the PCM treated group.}

Pre-treatment of P.guajava $1 \mathrm{~h}$ prior to PCM administration significantly protected the elevation of transaminases, ALP and total bilirubin activities. The activities of AST, ALT and ALP in the high dose P.guajava plus PCM treated group were $77.58 \pm 1.56 \mathrm{IU} \mathrm{L}^{-1}, 56.93 \pm 1.80 \mathrm{IU} \mathrm{L}^{-1}$ and $68.40 \pm 1.42 \mathrm{IU} \mathrm{L}^{-1}$, respectively. Similarly, the activity of total bilirubin significantly $(\mathrm{P}<0.05)$ decreased in P.guajava plus $\mathrm{PCM}$ treated group $\left(1.75 \pm 0.05 \mathrm{mg} \mathrm{dl}^{-1}\right)$ in comparison with the PCM induced hepatotoxic group $\left(4.84 \pm 0.16 \mathrm{mg} \mathrm{dl}^{-1}\right)$.

In this study, the plant P.guajava was observed to exhibit hepatoprotective effect as demonstrated by a significant decrease in the serum transaminases, ALP and total bilirubin level in rat induced with PCM hepatotoxicity. Moreover, the P.guajava enhanced the activities of antioxidant enzymes (GSH, GPx, SOD and CAT) against the PCM-induced hepatotoxicity in these animals as indicated in (Figure 6.4 (A-D)), suggesting that the reduction of oxidative stress in this scenario likely plays a role in the mechanism of its hepatoprotective effects. The liver is a major target organ for toxicity of xenobiotics and drugs, because most of the orally ingested chemicals and drugs first go to liver where they are metabolized into toxic intermediates. Various pharmacological or chemical substances are known to cause hepatic injuries such as paracetamol and $\mathrm{CCl}_{4}$ (Gutiérrez et al., 2008). Excessive dose exposure to these hepatotoxins may induce acute liver injury characterized by abnormality of hepatic function and degeneration, necrosis or apoptosis of hepatocyte (Higuchi and Gores, 2003). With the increasing ingestion of drugs or exogenous chemicals, the possibility of liver injury 
will undoubtedly increase (Lee, 2003). At present, drug or chemical-induced liver injury has become a major clinical problem. Much of attention should be paid to the mechanisms involving drug or chemical-induced liver injury. In addition, the search for effective therapeutical methods for the treatment of drug or chemical-induced liver injury is also very important (James et al., 2003). With respect to PCM dependent hepatotoxicity it is generally accepted that P450-dependent bioactivation of PCM is a main cause of potentially fulminant hepatic necrosis upon administration or intake of lethal dose of PCM (Masubuchi et al., 2005).In the course of acute liver failure, oxidative stress expressed by oxidant-antioxidant imbalance is profound in liver tissue. In recent studies PCM was found to induce substantial mitochondrial oxidative stress and peroxy nitrite formation (Knight et al., 2001) .This oxidative stress preceded cell injury by several hours (Jaeschke , 2003) and free radical scavengers attenuated PCM induced liver injury (Knight et al., 2002). Serum transaminases (AST \& ALT) and ALP activities have long been considered as sensitive indicators of hepatic injury and results indicate increased levels of serum transaminases was noted(Jain et al., 2003). ALP has been attributed to the damaged structural integrity of the liver, because these are cytoplasmic in location and are released into circulation after cellular damage (Recknagel et al., 1991). In the assessment of liver damage by PCM the determination of enzyme levels such as serum transaminases and ALP is largely used. Therefore, the marked release of transaminases and ALT into the circulation indicates severe damage to hepatic tissue membranes during PCM intoxication. In the present study, a single oral dose of PCM at $1 \mathrm{~g} / \mathrm{kg}$ caused a dramatic elevation in the serum transaminases and ALP activities (Ross, 2005), indicating an acute hepatotoxicity induced by administration of PCM (Table 6.6). High doses of PCM have been demonstrated to increase the serum levels of AST and ALT (Kozer et al., 2003). The significantly decreased serum transaminases and ALP activities in the P.guajava and silymarin administered groups prior to PCM demonstrated its hepatoprotective effect.

Serum bilirubin is one of the most sensitive tests employed in the diagnosis of hepatic diseases. It provides useful information on how well the liver is functioning (Harper, 1961). Bilirubin, a chemical breakdown product of hemoglobin, is conjugated with glucuronic acid in hepatocytes to increase its water solubility.Bilirubin concentration has been used to evaluate chemically induced hepatic injury. Besides various normal functions liver excretes the breakdown product of hemoglobin namely bilirubin into bile. Pre-treatment of P.guajava prevented severity of liver damage caused by PCM as evidenced by the low level of bilirubin in the serum (Table 5.4, 6.6). In another similar studies in rats (Roy et al., 2006, Roy and Das, 2010), hepatoprotective activity of methanolic extracts of p.guajava was evaluated in liver injury induced by both $\mathrm{CCl}_{4}$ and PCM, the results were as indicated in the (Table 6.7).

Table 6.7. Effect of Silymarin and p.Guajava methanolic leaf extract (MT) on serum ALT, AST, ALP, bilirubin level and liver weight in $\mathrm{CCl}_{4}$ and Paracetamol (PCM) induced acute liver injury in rats (Roy et al., 2006, Roy and Das, 2010).

[Values are mean \pm SE from 6 animals in each group]

\begin{tabular}{|c|c|c|c|c|c|c|}
\hline Treatment & $(\mathrm{mg} / \mathrm{kg})$ & $\begin{array}{l}\text { ALT } \\
(\mathrm{U} / \mathrm{L})\end{array}$ & $\begin{array}{l}\text { AST } \\
(\mathrm{U} / \mathrm{L})\end{array}$ & $\begin{array}{l}\text { ALP } \\
(\mathrm{U} / \mathrm{L})\end{array}$ & $\begin{array}{l}\text { Serum } \\
\text { bilirubin } \\
(\mathrm{mg} / \mathrm{dl})\end{array}$ & $\begin{array}{c}\text { Liver weight } \\
\text { (g/100gm body weight })\end{array}$ \\
\hline Vehicle control & .- & $72.86 \pm 6.19$ & $186.36 \pm 7.81$ & $398.18 \pm 6.73$ & $0.26 \pm 0.08$ & $3.2 \pm 0.09$ \\
\hline $\mathrm{CCl}_{4}$ control & .. & $384.00 \pm 25.02^{\mathrm{a}}$ & $642.20 \pm 31.01^{a}$ & $749.60 \pm 36.25^{\mathrm{a}}$ & $1.56 \pm 0.22^{\mathrm{a}}$ & $3.78 \pm 0.30^{\circ}$ \\
\hline $\mathrm{CCl}_{4}+$ Silymarin & 100 & $57.22 \pm 2.81^{* 8 *}$ & $205.46 \pm 6.12^{* * *}$ & $408.02 \pm 5.58^{8 * *}$ & $0.28 \pm 0.03^{* * *}$ & $3.10 \pm 0.06^{\mathrm{ns}}$ \\
\hline $\mathrm{CCl}_{4}+\mathrm{PGJ}$ & 250 & $60.10 \pm 7.70^{8}$ & $572.66 \pm 43.16^{\text {ns }}$ & $539.96 \pm 79.45^{* 8 *}$ & $0.26 \pm 0.11^{* * *}$ & $3.18 \pm 0.07^{\text {as }}$ \\
\hline $\mathrm{CCl}_{4}+\mathrm{PGJ}$ & 500 & $16.72 \pm 4.09^{* *}$ & $151.74 \pm 13.95^{* * *}$ & $488.82 \pm 10.01^{* *}$ & $0.26 \pm 0.05^{* * *}$ & $2.99 \pm 0.12^{*}$ \\
\hline
\end{tabular}

After $48 \mathrm{hr}$ of administration of both PCM and $\mathrm{CCl}_{4}$ the serum levels of ALT, AST, ALP and bilirubin were markedly increased P.guajava methanolic extracts $(250 \mathrm{mg} / \mathrm{kg} \& 500 \mathrm{mg} / \mathrm{kg})$ significantly reduced the elevated serum levels of AST, ALT, ALP and blirubin, the effect with $250 \mathrm{mg} / \mathrm{kg}$ is less effective than the effect with $500 \mathrm{mg} / \mathrm{kg}$. Both $\mathrm{PCM}$ and $\mathrm{CCl}_{4}$ induced the increase in liver weight, due to the blocking of secretion of hepatic triglyceride in to the plasma. However the higher dose of the methanolic extract $(500 \mathrm{mg} / \mathrm{kg}) \mathrm{prevented}$ the increase in liver weight when compared to hepatotoxin treated control. The hepatotoxic effects of both PCM and $\mathrm{CCl}_{4}$ are largely due to generation of free radicals. Therefore drugs having antioxidant activity are effective in treating $\mathrm{PCM}$ and $\mathrm{CCl}_{4}$ induced hepatotoxicity by scavenging the free radicals generated by the action of both PCM and $\mathrm{CCl}_{4}$.Different extracts of P.guajava including methanolic extract reported to increase the reduction of DPPH (Qian and Nihorimbere, 2004). Therefore the methanolic extracts of P.guajava Linn leaves showed good 
hepatoprotective activity in $\mathrm{PCM}$ and $\mathrm{CCl}_{4}$ induced liver damage. The hepatoprotective activity may be due to the antioxidant effect of the plant. Similar hepatoprotective activity of aqueous extracts of P.guajava was also determined in the study designed to investigate the effects of aqueous extract of Psidium guajava leaves on the histology and biochemical indices of liver function as well as hematological indices in rats (Uboha et al., 2010). The results of this study suggested that aqueous extract of Psidium guajava leaves may be hepatoprotective, and not hepatotoxic, with hematopoietic potentials in both male and female rats. The photochemical report of this study suggested that the hepatocellular function-enhancing effect of the extract may result from the action of the various extracts' contents, especially the presence of flavonoids which have been reported to have antioxidative effects (Middleton, 1996).

In another comparative study as indicated in (Table 5.4) by (Roy and Das, 2010) designed to evaluate the hepatoprotective activity of different extracts (petroleum ether, chloroform, ethyl acetate, methanol and aqueous) of $P$. guajava in acute experimental liver injury induced by carbon tetrachloride and paracetamol. The effects observed were compared with a known hepatoprotective agent, silymarin $(100 \mathrm{mg} / \mathrm{kg})$. The methanolic extract of Psidium guajava leaves showed significant hepatoprotective activity when administered at doses of $200 \mathrm{mg} / \mathrm{kg}$ orally. The effect produced by the dose of methanolic extract of $P$. guajava leaves was similar to that produced by silymarin $(100 \mathrm{mg} / \mathrm{kg})$, a well known hepatoprotective agent. Damage induced in the liver is accompanied by the increase in the activity of some serum enzymes. In the acute liver damage induced by different hepatotoxins, The anti-hepatotoxic action of $P$. guajava methanolic leaf extract was substantiated by significant attenuation of the increased levels of serum enzymes,aspartate aminotransferase, alanine aminotransferase, alkaline phosphatase and bilirubin in carbon tetrachloride and paracetamol induced hepatotoxicity than the other extracts. The $\mathrm{CCl}_{4}$ and PCM induced significant increase in liver weight was also observed in the study, which is due to blocking of secretion of hepatic triglycerides into the plasma. Silymarin and methanolic extract of Psidium guajava $(200 \mathrm{mg} / \mathrm{kg}$ ) also prevented the increase of liver weight in rats. Therefore methanolic extract of leaves of Psidium guajava plant possesses better hepatoprotective activity compared to other extracts. It was suggested in the study as the hepatoprotective activity may be due to the antioxidant effect of the plant.

In another study in Egypt (Osman et al., 2011) the hepatoprotective effect of guava against carbon tetrachloride-induced hepatotoxicity in rats liver was evaluated (Table 5.4), a significant decrease in the total protein and serum albumin contents was observed in treated rats with carbon tetrachloride. However significant increase in the serum total protein content and albumin were noticed in the rats treated with ethanolic extracts or silymarin when compared with $\mathrm{CCl}_{4}$-treated group and a significant increase in liver homogenate MDA level, activities of lysosomal enzymes(ACP, $\beta$-GAL and $\beta$-NAG) and activities of ALT, AST, GGT was observed in $\mathrm{CCl}_{4}$ alone treated rats when compared with the normal control but the remarkably reduction in the homogenate MDA levels or lipid peroxidation, the activities of ALT, AST, GGT and lysosomal enzymes (ACP, $\beta$-GAL and $\beta$-NAG) were noticed in the rats treated with ethanolic extracts or silymarin and these were no significant difference when compared with normal control group. These results indicated that the active ingredient of the p.guajava extracts have an inhibitory effects on membrane permeability of lysosomes. It may be due to the effect of antioxidant compounds present on the ethanolic extracts on the constituents of phospholipids bilayers of the membrane of rat liver lysosomes. This inhibitory effect appeared to have stabilizing effect on the membrane fluidity.

6.2.2. Effect of P.Guajava on reduced glutathione (GSH), Glutathione Peroxidase (GPx), superoxide dismutase (SOD) and Catalase (CAT) activities.

In the study (Tajua et al., 2010)Effect of P.guajava on Reduced glutathione (GSH), Glutathione peroxidase (GPx), superoxide dismutase (SOD) and Catalase (CAT) activities was evaluated in the rats liver homogenate.The results was as indicated in the (Table 5.4) and figures below:- 
Figure 6.4 A

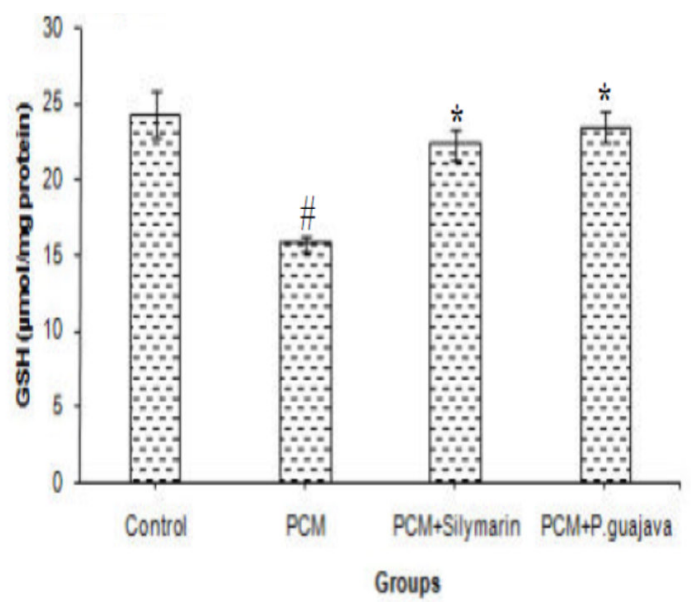

Fig 6.4 C

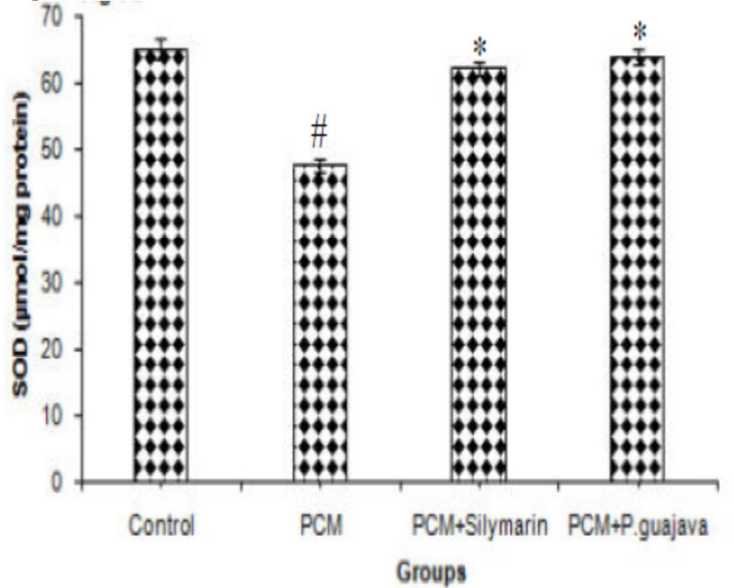

Figure 6.4 B

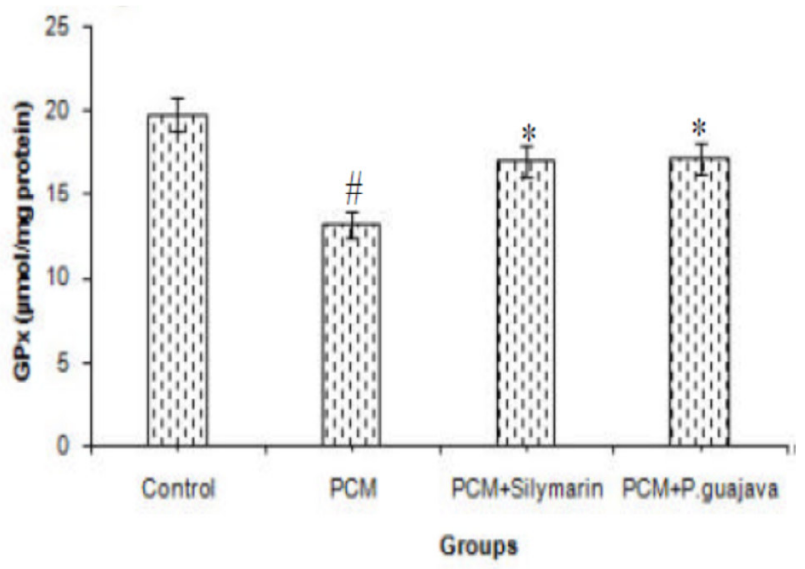

Figure 6.4 D

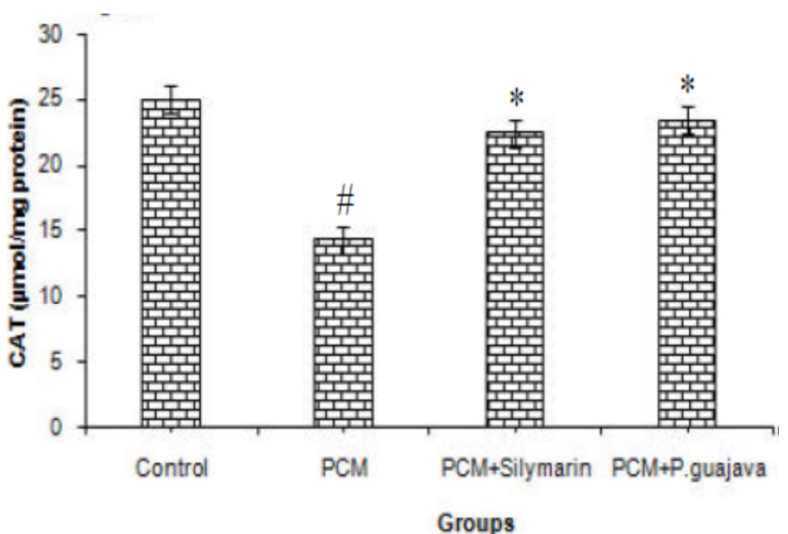

Figure 6.4(A-D) Hepatoprotective effect of P.guajava on liver. GSH (Figure 5.4A), GPx (Figure 5.4B), SOD (Figure 5.4C) and CAT (Figure 5.4D) level in PCM induced hepatotoxicity in rat. Each bar represents the mean \pm SD of six animals. \# P $<0.05$ Bonferroni's multiple comparison tests (BMRT)) significant difference from control. *P $<0.05$ (BMRT)) significant difference from PCM treated group. (Tajua et al., 2010)

Reduced glutathione is a substrate for glutathione related enzymes, and a regenerator for alphatocopherol. Therefore, it plays an important role in the antioxidant defense system (Meister, 1991). It is well known that a large dose of PCM causes hepatic GSH depletion because NAPQI reacts rapidly with glutathione (Masubuchi et al., 2005), which consequently exacerbates oxidative stress in conjunction with mitochondrial dysfunction. The GPx present in the cells can catalyze this reaction. Depletion of GSH below a threshold value was associated with a significant conversion of xanthine dehydrogenase to reversible xanthine oxidase, a superoxide radical generation reaction catalyzing enzyme (Cighetti et al., 1993). In this study, the hepatic content of GSH and GPx were found to be decreased significantly in PCM intoxicated rats compared with the control rats (Figure 6.4A and 6.4B). However, concomitant administration with P.guajava significantly prevented the PCM induced depletion of hepatic GSH and GPx, indicating the antioxidant effect P.guajava and silymarin in PCM intoxicated rats (Yin and Chin, 2007). All evidence, including serum enzyme activity, GSH level and damage markers show that P.guajava diet could decrease PCM induced oxidative stress. Living tissues are endowed with innate antioxidant defense mechanisms, such as the presence of the enzymes superoxide dismutase (SOD), catalase (CAT) and glutathione peroxidase (GPx) (Qian and Nihorimbere, 2004). A reduction in the activities of these enzymes is associated with the accumulation of highly reactive free radicals, leading to deleterious effects such as loss of integrity and function of cell membranes (Sheela and Angusti, 1995). Antioxidant enzymes such as SOD and CAT are easily inactivated by lipid peroxides or reactive oxygen species, which results in decreased activities of these enzymes in PCM toxicity (Gao et al., 2006).CAT is most abundant in the liver and is responsible for the catalytic decomposition of $\mathrm{H}_{2} \mathrm{O}_{2}$ to oxygen and water.SOD is an extremely effective antioxidant enzyme, and is responsible for catalytic dismutation of highly reactive and potentially toxic superoxide radicals to $\mathrm{H}_{2} \mathrm{O}_{2}$ (Reiter et al., 2000). The antioxidant effects of P.guajava and silymarin on the PCM induced depletion of hepatic antioxidant enzymes are presented in (Figure 6.4C and 6.4D). The activities of SOD 
and CAT in the PCM group were significantly decreased when compared with the control group. The results strongly suggest that the significant decrease of hepatic CAT and SOD activities observed in rats treated with PCM may be largely affect due to increased free radical production caused by administration of PCM (Krishnakantha and Lokesh, 1993). In rats treated with P.guajava, however, the activities of these antioxidant enzymes were significantly higher than in the rats exposed to PCM alone. P.guajava is similarly rich in phytochemical and exhibits antioxidant capacity against oxidative stress (Qian and Nihorimbere, 2004). Hypopharyngeal gland protein of rat enhances the proliferation of primary cultured rat hepatocytes invitro and this protein was present in P.guajava (Yin and Chin, 2007). All evidence, including serum enzyme activity, GSH level and damage markers show that a P.guajava diet could decrease PCM-induced oxidative stress.

In the similar study in Egypt (Osman et al., 2011) levels of superoxide dismutase(SOD), Catalase(CAT), glutathione-S transferase(GST), reduced glutathione (GSH) and lipid peroxidation was evaluated.As indicated from the results (Table 5.4) in hepatoprotective period, treated rats with carbon tetrachloride showed a significant decrease in the GST,SOD,CAT and GSH activity. Treatment rats with guava leaves ethanolic extracts or silymarin significantly increased the GST, SOD, CAT and GSH activity when compared with $\mathrm{CCl}_{4}$-treated group. Guava leaves ethanolic extract exerted a highly inhibitory effect on the decrease of GST, SOD, CAT and GSH activity. In the curative period as can be seen, the highest increase on homogenate GST, SOD, CAT and GSH activity was noticed in the rats treated with guava leaves ethanolic extracts with no significant difference when compared with normal group. This potential antioxidant activity may be due to the high content of phenolic compound in guava leaves ethanol extract that played a significant role on the antioxidant activity as stated by (Qian and Nihorimbere, 2004), the study investigating antioxidant power of phytochemicals from Psidium guuuajava.

Malondialdehyde(MDA), a stable metabolite of the free radical mediated lipid peroxidation cascade, was widely used as marker of lipid peroxidation.In the hepatoprotective period, a significant increase in liver homogenate MDA level was observed in $\mathrm{CCl}_{4}$ alone treated rats when compared with the normal control group. However, $\mathrm{CCl}_{4}$ induced elevation of the liver homogenate MDA levels were lowered significantly by the treatment of the rats with the guava leaves ethanolic extracts or silymarin when compared with $\mathrm{CCl}_{4}$-treated group. The remarkably reducion in the homogenate MDA levels were noticed in the rats treated with ethanolic extracts or silymarin and these were no significant difference when compared with normal control group. In the curative period, the same trend was observed in treatment animals with guava leaves ethanolic extracts or silymarin significantly which reversed the elevation of hepatic MDA formation when compared with $\mathrm{CCl}_{4}$ treated group. Also no significant effects were observed between the rats treated with guava leaves ethanolic extracts or silymarin and normal control.These results are in agreement with (Teselkin et al., 2000), who demonstrated that antioxidants prevent $\mathrm{CCl}_{4}$ toxicity, particularly hepatotoxicity, by inhibiting lipid peroxidation

Histopathological studies, showed paracetamol and $\mathrm{CCl}_{4}$ to produce extensive vascular degenerative changes and centrilobular necrosis in hepatocytes. Treatment with silymarin and P.guajava extract produced mild degenerative changes and absence of centrilobular necrosis when compared with control. Liver sections from control rats showed normal lobular architecture and normal hepatic cells with a well-preserved cytoplasm, nucleus and nucleoli were defined (Figure 6.4A). Whereas rat treated with PCM showed marked regenerative activity in the form of binucleation, prominent nucleoli, nuclear enlargement, loss of nucleus, centrilobular necrosis, and kupffer cells were hyperplastic (Figure 6.4B). No significant morphological changes were noted in liver of animals given only silymarin, as compared to that of animals in the control group (Figure 6.4C). Treatment with P.guajava showed normal lobular structure with hardly ascertainable regenerative activity in PCM-challenged animals (Figure 6.4D), similar observation was observed in(Roy et al., 2006, Osman et al., 2011, Roy and Das , 2010, Sambo et al., 2009, Uboha et al., 2010).An agreement was observed In the study mentioned above (Osman et al., 2011) Significantly increases were found in the activities of SOD and CAT enzymes when compared with $\mathrm{CCl}_{4}$-treated group. The content of reduced glutathione and GST in all treatments generally decreased as compared with normal group except treatment rats with guava leaves ethanolic extracts, which cause significant increase in the reduced glutathione content when compared with other treatments during hepatoprotective and curative periods with no significant difference when compared with normal control group. This potential antioxidant activity may be due to the high content of phenolic compound in guava leaves ethanol extract that played a significant role on the antioxidant activity as stated by (Tachakittirungrod et al., 2007). 


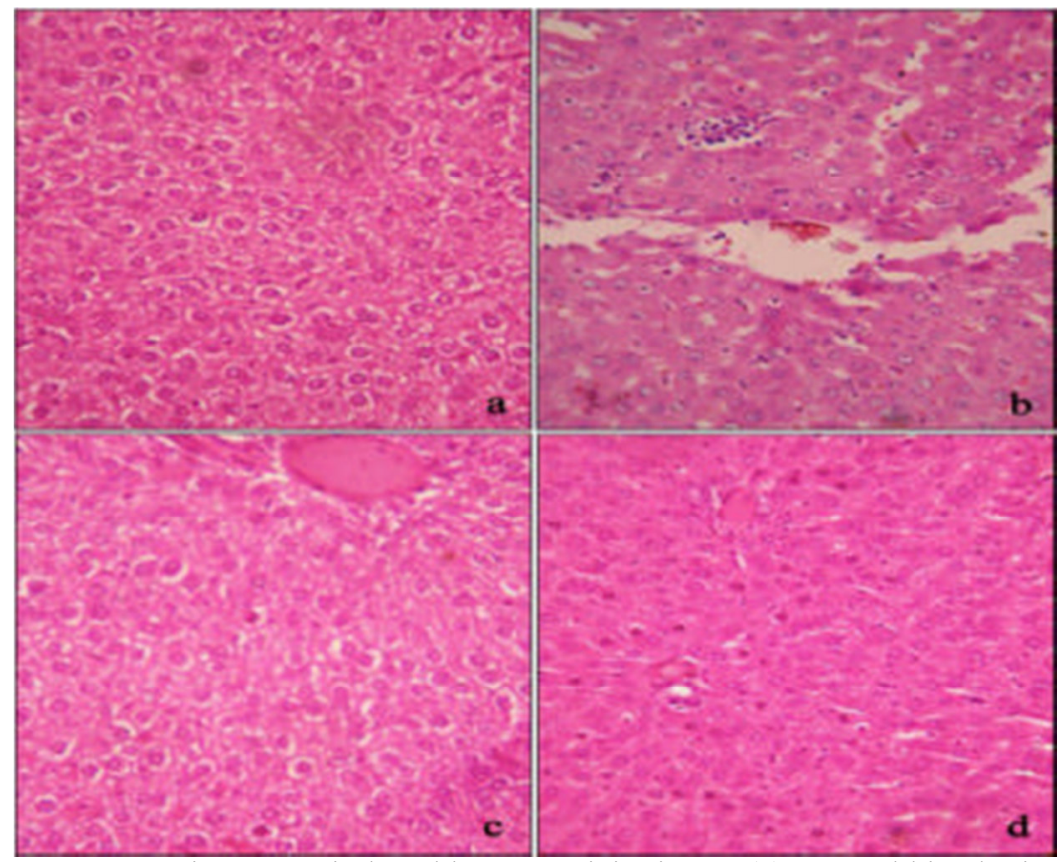

Figure 6.5 Effect of P.guajava against PCM induced hepatotoxicity in rat. (a) Normal histological appearance of the liver of control rat, (b) PCM induced hepatotoxicity in rat, (c) PCM + Silymarin pretreatment, (d) PCM + P.guajava pretreatment(Tajua et al., 2010).

Taken together, these findings, suggest that the aqueous, ethanolic and methanolic extracts from leaves of p.guajava exhibit hepatoprotective effect which was demonstrated by a significant decrease in the serum transaminases, ALP and total bilirubin level in rat induced with PCM and $\mathrm{CCl}_{4}$ hepatotoxicity. Moreover, the P.guajava enhanced the activities of antioxidant enzymes (GSH, GPx, SOD and CAT) against the PCM and $\mathrm{CCl}_{4}$-induced hepatotoxicity in these animals, suggesting that the reduction of oxidative stress in this scenario likely plays a role in the mechanism of its hepatoprotective effects.

\section{CONCLUSION}

Polyherbal therapy is a pharmacological principle that has the advantage of producing maximum therapeutic efficacy with minimum side effects and, according to the World Health Organization (WHO).Herbal drugs are frequently considered to be less toxic and free from side effects than synthetic drugs.

Phytochemical investigation of different extracts of p.guajava show that it contains carbohydrates,tannins, flavonoids, saponins, steroids, proteins, aminoacids, reducing compounds,alkaloids, polyphenols, glycosides and alkaloids.

Many pharmacological studies have demonstrated the ability of this plant to exhibit antioxidant, hepatoprotective, anti-allergy, antimicrobial, antigenotoxic, antiplasmodial, cytotoxic, antispasmodic, cardioactive, anticough, antidiabetic, anti-inflammatory and antinociceptive activities, supporting its traditional uses.

Extracts of p.guajava act as antioxidant via free radical scavenging and reducing of oxidized intermediates the phenolic content in guava leaf fraction played a significant role on the antioxidant activity.

Guava consumption resulted in significant increase in the levels of total antioxidants and reduced oxidative stress, as indicated by decreased levels of antioxidant enzymes (glutathione peroxidase and glutathione reductase).

Ethanol extracts of fruit peels of p.gajava had high radical scavenging acivities and also had high total phenolic content.

Guava (Psidium guajava) fruit is considered a highly nutritious fruit because it contains a high level of ascorbic acid (50-300 mg/100 $\mathrm{g}$ fresh weight).

P.guajava can be used as a safe, cheap, and effective alternative chemopreventive and protective agent in the management of liver diseases.

It exhibit hepatoprotective effect which was demonstrated by a significant decrease in the serum transaminases, ALP and total bilirubin level in rat induced with $\mathrm{PCM}$ and $\mathrm{CCl}_{4}$ hepatotoxicity. Moreover, the P.guajava enhanced the activities of antioxidant enzymes (GSH, GPx, SOD and CAT) against the PCM and $\mathrm{CCl}_{4}$-induced hepatotoxicity in these animals, suggesting that the reduction of oxidative stress in this scenario likely plays a role in the mechanism of its hepatoprotective effects. 


\section{RECOMENDATION}

* Plant derived natural products such as flavonoids, terpenoids, carbohydrates, tannins, saponins, steroids, proteins, amino acids and Vitamin $\mathrm{C}$ etc should received considerable attention in recent years due to their diverse pharmacological properties including antioxidant and hepatoprotective activity

* Much of attention should be paid to the medicinal values of p.guajava with special reference to its antioxidant and hepatoprotective activities.

* Guava fruit should be supplemented as an intervention mechanism for diseases associated with oxidative stress.

* Further studies need to confirm the potential active constituents and antioxidative and hepatoprotective activity of this active constituents of guava extracts, but more importantly, if such activity exists in the fruit, which is the part of the plant that is consumed.

* In these and other future studies, the amount of antioxidant tested should be compared to what is actually biologically available in the blood after the guava fruit is consumed.

\section{Consent to publish}

Not applicable

\section{Competing interest}

We declared no competing interests influenced this study.

\section{Funding}

Addis Ababa University

\section{Author Contributions}

TM made substantial contributions in conception, designing the study, analysis, interpretation of data and approval of final version to be published. HA participated in designing the study, analysis, interpretation of the data and manuscript writing. We agreed to be accountable for all aspects of the work.

\section{Acknowledgment}

we would like to thank Addis Ababa University for providing the fund.

\section{REFERENCES}

Akanji M, Adeyemi S, oguntoye O and sulyman F. (2009). Psidium guajava extract reduces trypanosomosis associated lipid peroxidation and raises glutathione concentrations in infected animals. EXCLI Journal, $8: 148-154$

Arnao M, Cano A, Hernandez R, Garcia C and Acosta M. (1996).inhibition by L-ascorbic acid and other antioxidants of the 2, 20-azino-bis (3-ethylbenzthiazoline-6-sulfonic acid) oxidant Ion catalyzed by peroxidase: a new approach for determining total antioxidant status of Foods. Analyt. Bioch. 236:255261.

Brent J and Rumack B. (1993). Role of free radicals in toxic hepatic injury. II. Are free radicals the cause of toxin-induced liver injury? J. Toxicol .Clin. Toxicol. 31: 173-96.

Chanda S and Dave R. (2009). In vitro models for antioxidant activity evaluation and some medicinal plants possessing antioxidant properties. Afr. J. Microbiol. Resea. 3(13):981-996

Chin Y and Der D. (1994). Scavenging effect of methanolic extracts of peanut hulls on free radicals and activeoxygen species. J. Agricult. Food Chem. 42: 629-632.

Cighetti G, Debiasi S and Paroni R. (1993). Effect of glutathione depletion on the conversion of xanthine dehydrogenase to oxidase in rat liver. J. Biocheml. PharmacoL. 45:2359-2361.

Cohen G and Heikkila R. (1974).The generation of hydrogen peroxide, superoxide and hydroxyl radical by Phydroxyl dopamine, dialuric acid and related cytotoxic agents. Jour.Biolo. Chem. 249: 2477-2452.

Dorman D and Hiltunen R (2004).Fe (III) reductive and free radical-scavenging properties of summer savory (Satureja hortensis L.) extract and subtractions. Food Chem. 88:193-199.

Gao J, Igalashi K and Nukina M. (1999).Radical scavenging activity of phenylpropanoid glycosides in Caryopteris incana. Biosci.Biotechnol. Biochem. 63: 983-988.

GAO J, Chen J, Tang X, Pan L, Xu L, Zhao and Xu Q. (2006). Mechanism underlying mitochondrial protection of asiatic acid against hepatotoxicity in mice. J. Pharm. Pharmacolo. 58:227-233.

Gupta G, Chahal J and Arora D. (2011).Psidium guajava Linn: Current Research and Future Prospects. J.PharM. Resea, 4(1):42-46.

Gutiérrez R, Mitchell S and Solis R. (2008). Psidium guajava: a review of its traditional uses, photochemistry and pharmacology. J. Ethnopharmacol. 117(1): 1-27.

Harper H. (1961).The functions and tests of the liver. Review of Physiological Chemistry. Lange MediC.Publis. $2: 271-283$

Higuchi H and Gores G. (2003). Mechanisms of liver injury: an overview. Curr Molecul. Medic. 3:483-490.

Jaeschke H. (2003). Oxidant stress precedes liver injury after acetaminophen in cultured mouse hepatocytes. Toxicol. Scie. 72:10. 
Jain N, Dhawan K, Malhotra S, Siddiqui S and Singh R. (2003). Biochemistry of fruit ripening of guava (Psidium guajava L.). Compositional and Enzymatic Changes, 58:309-315.

James P,Mayeux R and Hinson A. (2003).Acetaminophen-induced hepatotoxicity.Drug Metabolism and Disposition, 31:1499-1506.

Joseph B, Priya M. (2011). Review on nutritional, medicinal and pharmacological properties of guava (psidium guajava linn.).Int.J.of pharma \&bio science, 2(1):53-69.

Jiménez-Escrig A, Rincón M, Raquel R, and Saura F. (2001).A Guava Fruit (Psidium guajava L.) as a New Source of Antioxidant Dietary Fiber.J. Agric. Food Chem. 49 (11): 5489-5493.

Kamath J, Rahul N, Ashok Kumar C and Lakshmi S. (2008) Psidium guajava L: A review, Intern. J.Green Pharm. 2 (1): 9-12.

Krishnakantha T and Lokesh B. (1993). Scavenging of super oxide anions by spice principles.Ind.J. Exper. Biolo.30:133-134.

Knight R, Kurtz A, Bajt L, Hinson A and Jaeschke H. (2001). Vascular and hepatocellular peroxynitrite formation during acetaminophen-induced liver injury: Role of mitochondrial oxidant stress.Ox.Univ.Press. 62:212-220.

Knight R, Ho Ye-shih H, Farhood A and Jaeschke H. (2002).Peroxynitrite is a critical mediator of acetaminophen hepatotoxicity in murine livers: protection by glutathione. J. PharmacOL. ExperiM. TherAP. 303:468-475.

Kozer E, Evans S, Barr J, Greenberg R, Soriano I, and Bulkowstein M. ( 2003). Glutathione, glutathionedependent enzymes and antioxidant status in erythrocytes from children treated with high-dose paracetamol. British J. Clini. harmacol. 55: 234-40.

Lee W. (2003).Drug-induced hepatotoxicity. New England J. MediC. 349: 474-481.

Lutterodt G. (1992). Inhibition of Microlax-induced experimental diarrhea with narcotic-like extracts of Psidium guajava leaf in rats. J.Ethno pharmacol. 37(2): 151-157.

Malcolm S and Sofowora E. (1969). Antimicrobial activity of selected Nigerian folk remedies and their constituent plants. Lloydia, 32: 512-517.

Marquina V, Araujo L, Ruíz J, Rodríguez-Malaver A and Vit P. (2008).Composition and antioxidant capacity of the guava (Psidium guajava) fruit, pulp and jam. Arch Latinoam Nutr. 58(1):98- 102.

Masubuchi Y, Suda C and Horie T. (2005). Involvement of mitochondrial permeability transitio in acetaminophen induced liver injury in mice. J.Hepatol. 42:110-116.

Meister A. (1991). Glutathione deficiency produced by inhibition of its synthesis, and its reversal; applications in research and therapy. Pharmacology and Therapeutics, 51:155-194.

Middleton E. (1996). Biological properties of plant flavonoids: An overview. Inter. J. Pharm. 34(95):344-348.

Mitsuda H, Yasumoto K, and Iwami K. (1996). Antioxidative action of indole compounds during the autoxidation of linoleic acid. Eiyo to Shokuryo, 19:210-214.

Mittal P, Gupta V, Kaur G, Garg A and Singh A. (2010). Photochemistry and pharmacological activities of psidium guajava.IJPSR, 1 (9): 9-19

Nabasree D and Bratati D. (2004). Ant ioxidant activity of Piper betle L. leaf extract in vitro. Food Chemistry, $88,219-224$.

Namiki M. (1990). Antioxidants / Antimutagens in food. Critical Review of Food Science and Nutrition, 29: 273-300.

Nor N and Yatim A. (2009). Effects of pink guava (psidium guajava) puree supplementation on antioxidant enzymes activities and organs functions of spontaneous hypertensive rat. Prosiding Seminar Kimia Bersama UKM-ITB, 3: 9-11.

Ogunlana O. (2008). In vitro assessment of the free radical scavenging activity of psidium guajava. Journal of Agricult.Biologic. Scie. 4(6): 666-671.

Okonogi S, Tachakittirungrod S and Ikegami F. (2007). Antioxidant Active Principles Isolated from Psidium guajava Grown in Thailand. Scientia Pharmaceutica, 75:179-193.

Osman M, Ahmed M, Mahfouz S and Elaby S. (2011). Biochemical Studies on the Hepatoprotective Effects of Pomegranate and Guava Ethanol Extracts. New York Science Journal, 4 (3):27-39.

Polidori M, Stahl W, Eichler O, Niestroj I and Sies H. (2001). Profiles of antioxidants in human plasma. Free Rad Bio and Med. 30 (5): 456-462.

Qian H and Nihorimbere V. (2004). Antioxidant power of phytochemicals from Psidium guajava leaf. $J$. Zhejiang Univ. Sci. 5: 676-683.

Rahmat A, Abubakar M and Hambali Z. (2006).The effects of guava (psidium guajava) consumption on total antioxidant and lipid profile in normal male youth.Afr.J.food agric, nut and devel.6 (2):1-12.

Recknagel R, Glende E and Britton R. (1991). Free radical damage and lipid peroxidation. CRC Press, Flori. 4: 401-436.

Reiter R, Tan D, Osuna C and Gitto E. (2000). Actions of melatonin in the reduction of oxidative stress. Journal 
of Biomedical Science, 7:444-458.

Ross I. (2005). Medicinal Plants of the World. Humana Press, New Jersey, USA, 3:263-26

Roy C, Kamath J. and Azad M. (2006).Hepatoprotective activity of Psidium guajava L leaf extract. Ind. J. Exp. Biol. 44(4):305-311

Roy C and Das A (2010). Comparative evaluation of different extracts of leaves of psidium guajava Linn for hepatoprotective activity.Pak. J. Pharm. Sci.23 (1):15-20.

Roy C and Das A. (2010). Effect of pidium guajava linn.Methanolic leaf extract on hepatoprotection.JPBMS, $1(1): 1-4$.

Sambo N, Garba S and Timothy H. (2009).effect of the aqueous extract of psidium guajava on erythromycininduced liver damage in rats. Nigerian Journal of Physiological Sciences, 24 (2): 171 -176.

Sangeetha B and krishnakumari S. (2010). Tephrosia purpurea (Linn.) pers: a folk medicinal plant ameliorates carbon tetrachloride induced hepatic damage in rats. Inte. J. Pharma. and Bio. Sci. 1(2):1-10

Sheela C and Angusti K. (1995). Antiperoxide effects of S-allyl cystein sulphoxide isolated from Allium sativum Linn and gugulipid in chlosterol diet fed rats. Ind. J. Exp. Bio.33:337-341.

Tachakittirungrod S, Okonogi S and Chowwanapoonpohn S. (2007). Study on antioxidant activity of certain plants in Thailand: Mechanism of antioxidant action of guava leaf extract. J.Food Chem. 103:381-388.

Tajua G, Jayanthia M, Nazeer bashab M, Nathiga K and Sivarajb A. (2010). Hepatoprotective Effect of Indian Medicinal plant Psidium Guajava Linn. Leaf extract on paracetamol induced liver toxicity in Albino rats. J. Pharm. Resea., 3(8):1759-1763

Teselkin Y, Babenkova I, Kolhir V,Baginskaya A, Tjukavkina N, Kolesnik Y,Selivanova I and Eichholz A. (2000).Dihydroquercetin as a means of antioxidative defence in rats with tetrachloromethane hepatitis. Phytother. Res. 14 (3): 160.

Thaipong K, Boonprakob U, Zevallos L and Byrne D. (2005). Hydrophilic and lipophilic antioxidant activities of guava fruits. Southeast Asian j trop med public health, 36:254-257.

Uboha F, Okonb I, Ekong M. (2010). Effect of Aqueous Extract of Psidium Guajava Leaves on Liver Enzymes, Histological Integrity and Hematological Indices in Rats. Journal of Gastroenterology Research, 3(1):32-38.

Vyas N, Tailang M, Narayan Prasad Gavatia N and Gupta B. (2010). Antioxidant potential of psidium guajava linn.Int. J. pharm.Tech. Rese. 2(1):417-419.

Yin C and Chin Y. (2007). Antioxidant activity and free radical-scavenging capacity of extracts from guava (Psidium guajava L.) leaves. Food chemistry, 101(2): 686-694. 